\title{
11. BUDGET OF POSTRIFTING SEDIMENTS IN THE GULF OF CALIFORNIA AND CALCULATION OF THE DENUDATION RATE IN NEIGHBORING LAND AREAS ${ }^{1}$
}

\author{
Gerhard Einsele, Institut für Geologie und Paläontologie, Universität Tübingen, \\ 7400 Tübingen, Federal Republic of Germany \\ and \\ Jeffrey W. Niemitz, Department of Geology, Dickinson College, Carlisle, Pennsylvania
}

\begin{abstract}
Using seismic records and porosity-depth curves, we calculate the volume of "dry" post-rifting sediment in the 4-m.y.-old central and southern Gulf of California (Fig. 1) to be approximately 12,500 $\mathrm{km}^{3}$. For an area of 127,000 $\mathrm{km}^{2}$, this volume represents a mean sedimentation rate of $2.5 \mathrm{~cm} / \mathrm{ky}$. for dry, solid material. Postrifting sediments on the proto-Gulf shelves $\left(65,000 \mathrm{~km}^{2}\right.$ ) may fill a $15,000 \mathrm{~km}^{3}$ volume (a mean sedimentation rate of $5.8 \mathrm{~cm} / \mathrm{ky}$. for dry, solid material).

Previous investigations of surface sediments and the results from holes drilled on DSDP Legs 64 and 65 allow us to estimate the contribution of principal sediment types, components, and grain size to the sediment budget for the southern and central Gulf. It has been assumed that vertical facies changes are insignificant. The results of our calculations are listed separately for postrifting sediments on oceanic crust and those on proto-Gulf shelves (Tables 3 and 4). For the study area as a whole, the following results may indicate the correct order of magnitude for the sediments deposited during the last 4 m.y.:

1) Sediment type (volume $\%$ of dry, solid sediment): shelf, $22 \%$; slope, $37 \%$; basin, $41 \%$.

2) Texture (wt. \%): sand, $13 \%$; silt, $48 \%$; clay, $39 \%$.

3) Components (wt. \%): "clay," $56 \%$; quartz (terrigenous), $8 \%$; biogenic silica, $14 \%$; calcium carbonate, $7 \%$; organic carbon, $2.3 \%$; others, $13 \%$.

Note that the contribution of the three principal sediment types to the total sediment volume does not correspond with the area (as a percentage) of the shelves, slope, and basins (28:51:21) at present (Fig. 6). Redepositional processes transporting sediments, chiefly from the slopes to the basins, explain this discrepancy.

Average sedimentation rates for the total study area are, for dry, solid material:

1) Total sediment, $3.6 \mathrm{~cm} / \mathrm{ky}$.

2) Terrigenous material, 2.5

3) Biogenic silica (opal), 0.5

4) Biogenic carbonate, 0.25

5) Organic matter, 0.35

If we consider the growth of the 4-m.y.-old postrifting Gulf from zero to its present extent, its mean sedimentation rate $(5 \mathrm{~cm} / \mathrm{ky}$.) is approximately the same as that on the proto-Gulf shelf $(5.8 \mathrm{~cm} / \mathrm{ky}$.).

From the input of terrigenous material, the mean denudation rate of the drainage area $\left(271,500 \mathrm{~km}^{2}\right)$ of the southern and central Gulf has been approximately $2 \mathrm{~cm} / \mathrm{ky}$. for the last $4 \mathrm{~m} . \mathrm{y}$. This rate is lower than most denudation rates that have been determined from sediment-load measurements for river basins with similar climates and relief. The characteristics of the drainage basin under study and causes for this discrepancy are discussed.
\end{abstract}

\section{INTRODUCTION}

Studies of the weathering of rocks and subsequent accumulation of sediments in subsiding basins are an important topic in several recent textbooks (e.g., Garrels and MacKenzie, 1971; Blatt, Middleton, and Murray, 1980). Quantitative data for these processes have been available for some areas, but in many regions the rates of denudation and accumulation are unknown or very uncertain. The Gulf of California and its drainage basin, in spite of some shortcomings, provide one of the best areas in which to examine this important problem.

An estimate of the sediment budget of this basin includes studies of several other important problems: the interaction between crustal movements and basin filling; the nature of terrigenous materials deposited in re-

\footnotetext{
${ }^{1}$ Curray, J. R., Moore, D. G., et al., Init. Repts. DSDP, 64: Washington (U.S. Govt. Printing Office).
}

lation to climate and relief in the source area and in the basin itself; and the contribution of biogenic material to the total sediment mass. The Gulf of California represents a particularly interesting study area for these problems, since it is a young (less than 4.0 m.y.) ocean basin formed by rifting and strike-slip movement (Moore and Curray, this volume, Pt. 2). Furthermore, the rather complicated pattern of sediment fill may also be typical of the initial stage of development of passive-margin ocean basins, even if their strike-slip component is less pronounced than in the Gulf of California.

Denudation rates on land can be evaluated in different ways. A common method is the measurement of sediment discharge from rivers, and many papers have dealt with this technique. Data gained by this method must be viewed with caution, however. Usually these measurements do not include rare events, for example, catastrophic floods, which may occur once in 10 or 100 years and carry more suspended and bed load than a longer period of normal river discharge. Many of these 
measurements are strongly affected by the activities of man (Meade, 1969; Morgan, 1979) and therefore yield denudation rates much higher than those of prehistoric times. Also, we commonly obtain averages for relatively short time spans which may not be representative of longer periods.

For these reasons, geologists have tried to derive long-term denudation rates for particular land areas from the volume of sediment accumulated in adjacent basins for a specific period of time (see, for example, Menard et al., 1965; Moore, 1969; Curray and Moore, 1971; Mathews, 1975; Roll, 1979). This has been done for the relatively short time spans of the Quaternary and Tertiary. However, in these cases time control and the extension of the drainage and accumulation areas (for example, sediment wedges of shelves, deltas, or submarine fans) are often uncertain. Probably the best results can be gained from studies of closed or semiclosed basins, for example, the Red and Black seas (Degens et al., 1978).

Chemical denudation, which in humid climates of low relief considerably surpasses the rates of mechanical denudation, may also be problematic (see, for example, Garrels and MacKenzie, 1971; Hohberger and Einsele, 1979). Dissolved constituents may be trapped by organisms and incorporated into the ultimate sink of the eroded material, the basinal sediments. In most cases, the fate of dissolved material remains more or less unknown. Clearly, quantification of the processes of the geologic cycle is extremely difficult and requires further study.

\section{BACKGROUND DATA}

\section{Characteristics of the Drainage Area: Sonoran Desert, Pacific Coastal Plain, Sierra Madre Occidental, and Peninsular Ranges Provinces}

In a study such as this the area being drained into the sediment basin and the volume and age of the sediment body in the basin must be determined.

For the Gulf of California, the first requirement, the drainage area, is easily established (Fig. 1), if the northern part of the Gulf and the Colorado River drainage basin can be excluded. During the humid periods of the Pleistocene, the Colorado drained a much larger area than at present (Rabbitt et al., 1969; Metzger et al., 1973), and it would be difficult to establish the average drainage area of the Colorado River for the last several million years. In contrast, the rivers entering the central and southern Gulf from the Mexican mainland appear to have had approximately constant drainage areas during the wet and dry periods of the Pleistocene. Therefore, we take the present drainage areas of these rivers as representative over several million years. The principal physiographic features of Mexico, the Sierra Madre Oriental and Occidental with the Central Mesa, were most likely formed during early Cenozoic time, and the grain of the present-day topography probably developed 7-10 Ma (King, 1969; Stewart, 1978).

Soil erosion is controlled by numerous variables (see, e.g., Wischmeier, 1977; Morgan, 1979). Under natural conditions the most important factors are rock type, climate, vegetation, and drainage basin characteristics such as area, steepness and length of slopes, and drainage density. For establishing a sediment budget of the Gulf of California, a brief survey of the characteristics of the drainage area will suffice.

\section{Geology and Rock Types}

The geology of the lands surrounding the Gulf of California has been presented by Allison (1964), van Andel (1964), and, more recently, by Gastil et al. (1975) and Abbott and Gastil (1979) for Baja California, and by Demant and Robin (1975) and McDowell and Keizer (1977) for mainland Mexico. Regional geologic maps have been prepared by Gastil and Krummenacher (1977). The rock types of the various drainage areas surrounding the Gulf have been determined using the official geologic survey map of Mexico, drawn on a scale of 1 : $2,000,000$. Although in Table 1 only a semiquantitative description is given, it can be seen that Cenozoic volcanic rocks ranging in composition from basalt to rhyolite, particularly andesitic rocks, predominate in the drainage areas. These are exposed chiefly in the highland of the Sierra Madre Occidental and the Peninsular Ranges of Baja California. Secondarily important are Tertiary and Quaternary continental sediments which occupy the lowlands near the coast, river valleys, and the foot of mountain ranges. A great part of these sediments is derived from Cenozoic volcanics, the other from Mesozoic and Tertiary granitic intrusives, Triassic to Cretaceous continental and marine sediments, and metamorphic rocks of differing ages. The second group of these rocks also delivers sediment directly into the Gulf. Within the drainage areas, neotectonic activity appears to be restricted to vertical movements, as evidenced by raised marine terraces (Ortlieb, 1978) that probably have little effect on the sediment budget.

\section{Climate, Vegetation, and Soils}

The study area lies in the transition zone between the hot, dry climate of the west coast and Sonoran Desert and the semiarid and wet climate of the southern and southeastern lowlands of Mexico (Strahler, 1969; Gierloff-Emden, 1970; Maderey Rascón, 1977). Annual rainfall increases from north $(<50 \mathrm{~mm})$ to south $(>1000$ $\mathrm{mm}$ ), as shown in Figure 2.

The Sierra Madre Occidental, with elevations up to 3000 meters, produces a wet, temperate climate dominated by coniferous forests. The desert vegetation of Baja California and the Sonoran Desert is well developed and diversified (Dunbier, 1968); however, barren soil and rock are frequently exposed. South of the Río Yaqui, dense shrubbery and thorn forest prevails; this is replaced in the uplands by thin deciduous and coniferous forests.

Chemical weathering is most prevalent during the short rainy seasons in these climates. Mechanical weathering prevails during the rest of the year. In the mountains, rivers cut deeply, exposing the volcanic rock. Coarse-grained material is concentrated in bajadas and on pediments (Dunbier, 1968). Fine-grained weathering products (clay and silt) are deposited in floodplains, 


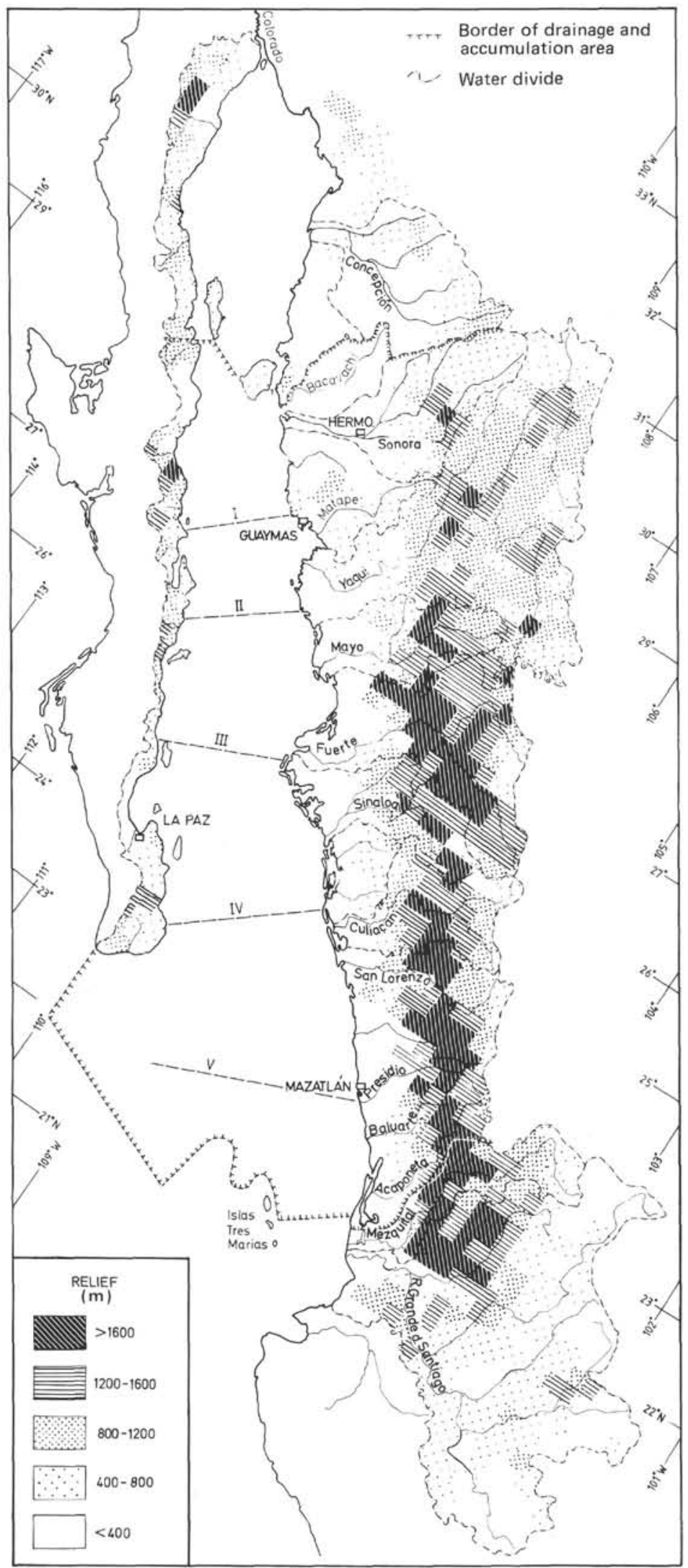

Figure 1. Relief map of the neighboring land areas with river catchments and limits of the accumulation area. Broken lines I-V locate cross-sections (see Figs. 11-15). 
Table 1. The drainage area for the central and southern Gulf of California.

\begin{tabular}{|c|c|c|c|c|c|c|}
\hline \multirow{2}{*}{$\begin{array}{l}\text { Watershed } \\
\text { (major river) }\end{array}$} & \multirow{2}{*}{$\begin{array}{l}\text { Area } \\
\left(\mathrm{km}^{2}\right)\end{array}$} & \multirow{2}{*}{$\begin{array}{c}\text { Mean } \\
\text { Relief } \\
(\mathrm{m})\end{array}$} & \multirow{2}{*}{$\begin{array}{c}\text { Mean } \\
\text { Runoff } \\
(\mathrm{mm} / \mathrm{y} .)\end{array}$} & \multicolumn{3}{|c|}{$\begin{array}{c}\text { Outcropping Rocks } \\
\text { or Sediments }(\%)\end{array}$} \\
\hline & & & & High & Medium & Low \\
\hline Baja California ${ }^{a}$ & 20,600 & 750 & $0-10$ & $\mathrm{Cv}$ & $\mathrm{Mi}$ & $\mathrm{Q}, \mathrm{Tm}$ \\
\hline Sonorab & 47,500 & 435 & 8 & $Q$ & $\mathrm{Mi}, \mathrm{Tc}$ & Met \\
\hline Yaqui & 71,300 & 860 & -40 & $\mathrm{Cv}$ & $\mathrm{Q}, \mathrm{Tc}$ & Ms, Met \\
\hline Mayo & 16,600 & 890 & 80 & $\mathrm{Cr}$ & Q & Tc, Ti,Ms \\
\hline Fuerte & 39,600 & 1230 & 123 & $\mathrm{Cv}$ & Q & $\mathrm{Ti}$ \\
\hline Sinaloa & 13,900 & 810 & 175 & $\mathrm{Cr}$ & Q. Tc & Met \\
\hline Culiacán & 16,800 & 770 & 188 & $\mathrm{Cv}$ & Q,Tc,Met & \\
\hline $\begin{array}{l}\text { San Lorenzo } \\
\text { to Acaponeta }\end{array}$ & 45,200 & 940 & $150-300$ & $\mathrm{Cv}$ & $\mathrm{Ti}$ & Q,Tc,Met \\
\hline Total & 271,500 & 820 & & $\mathrm{Cv}$ & $\mathrm{Q}, \mathrm{Tc}$ & $\begin{array}{l}\text { Mi,Ti,Met, } \\
\text { Ms }\end{array}$ \\
\hline
\end{tabular}

Note: $\mathrm{Q}=$ Quaternary sediments; $\mathrm{Tc}, \mathrm{Tm}=$ Tertiary (and Cenozoic) continental or marine sediments; $\mathrm{Ti}=$ Tertiary (granitic) intrusives; $\mathrm{Cv}=$ Cenozoic volcanic rocks of variable composition (basaltic to rhyolitic, but predominantly andesitic): $\mathrm{Ms}=$ Mesozoic (Triassic to Cretaceous) continental and marine sediments; $\mathrm{Mi}=$ Mesozoic (granitic) intrusives; Met = metamorphic rocks.

a South of Isla Angel de la Guarda.

${ }^{b}$ Including the smaller Ríos Bacavachi and Matape.

desert playas, and deltaic plains or are swept into the Gulf. There they form uniform clayey silts or silty clays, which are discussed below as the terrigenous components in Gulf sediments.

\section{Hydrography and Relief}

Table 1 lists the main drainage areas for major rivers and their coastal areas. The small catchment basins for the Baja Peninsula are combined (Fig. 1). The catchments north of Rio San Ignacio and south of the Middle America Trench, south of Islas Tres Marias, are not considered in this study. Thus, the drainage area for the study area is approximately $256,000 \mathrm{~km}^{2}$ for the central and southern Gulf of California. Normally, the Rios Fuerte, Culiacán, Yaqui, Sinaloa, and Mayo are permanent, whereas other smaller rivers are intermittent. Some smaller streams, especially on the Baja Peninsula, are ephemeral, flowing only after storms.

The change in climatic zones from northwest to southeast is reflected not only in rainfall but also in mean annual runoff of the major rivers (Table 1 , after Dunbier, 1968, and Fig. 2B after Maderey Rascón, 1977). Note that the annual runoff increases from 0-10 $\mathrm{mm}$ in the northwest to $150-300 \mathrm{~mm}$ in the southeast. These data might suggest that sediment transport from the continent into the Gulf increases in proportion to the mean annual runoff. This, however, is not necessarily true, since flooding, which occurs in the region as a whole, may be more important. Several authors (Langbein and Schumm, 1958; Selby, 1974; Butzer, 1976) have suggested that, under comparable conditions, the sediment yield of rivers reaches a maximum in the zone of semiarid climate, with approximately $300 \mathrm{~mm} / \mathrm{y}$. mean precipitation.

Relief is also an important factor controlling sediment yield of rivers. Ahnert (1970) suggests a linear relationship between mean relief of a catchment and its mean denudation rate for mid-latitude river basins. Average relief for $20 \times 20 \mathrm{~km}$ squares has been determined for the study area (Fig. 1). For the large river basins, the values of mean relief are listed in Table 1. The result is that the rivers in the southern half of the study area have a considerably higher relief than those in the northern half or on Baja California. The total area has a mean relief of 820 meters (see also Fig. 3), which is comparable to the basins of the Green, Escalante, and Dirty Devil rivers of Utah (Ahnert, 1970) but somewhat lower than the mean relief of the Colorado River above Cisco, Utah.

Measurement of slope angles and slope length may be a better method for characterizing the drainage areas (Wishchmeier, 1977). As this is time-consuming, only one of the different drainage areas, the Rio Yaqui Basin, was measured; it was assumed to be representative of the whole (Figs. 4 and 5). It was determined that $86 \%$ of the total area of the Rio Yaqui Basin is occupied by slopes of between 10 and $40 \%\left(5.7-21.8^{\circ}\right)$. This distribution of slope angles corresponds to a mean relief of 860 meters. Taking the sine of the mean slope angle (sin $16^{\circ}=0.273$ ) and comparing it to others (Ahnert, 1970) reveals that the mean slope of the Rio Yaqui Basin has a higher sine-of-slope angle than most North American river basins and nearly reaches the lowest values of Alpine drainage systems $(0.287-0.410)$. This is due to the densely spaced river courses in the study area, which intensify the efficiency of a medium-to-high relief.

\section{Characteristics of the Depositional Area: Central and Southern Gulf of California}

A more difficult task is determining the sediment body delivered by rivers. The Gulf of California is not a closed basin, but exchanges its water mass with the Central Pacific Ocean through its wide and deep opening to the south (Fig. 6). For reasons which are discussed later, the loss of sediment to the Pacific Ocean is, however, probably small. Furthermore, the Gulf does present a number of particular advantages for this kind of study:

1) The Gulf of California has been investigated at least as carefully as most other comparable areas (for example, the Black and Red seas, the Persian Gulf, the Mediterranean Sea, some shelf areas, marine deltaic cones, and submarine fans (see van Andel and Shor, 1964, and Robinson, Lewis et al., in press). Specifically, seismic profiling is closely spaced (Fig. 7) and the coverage is extensive (Moore, 1973; Sharman, 1976; Niemitz and Bischoff, 1981).

2) The age of rifting (4 Ma) and hence the area of postrifting sea floor, is well known from magnetic anomalies at the mouth of the Gulf (Larson, 1972, and biostratigraphic evidence from Sites 474-476, this volume, Pt. 1).

3) In the postrifting part of the Gulf thicknesses of unconsolidated sediment overlying older basement or indurated sediments are easily derived from seismic reflection profiles (Fig. 7). The interpretation of seismic records is further facilitated by sonobuoy data and measurements of sonic velocities on samples from Legs 64 and 65 .

4) The rugged topography of the sea floor (Fig. 6) favors the entrapment of sediments within the Gulf 

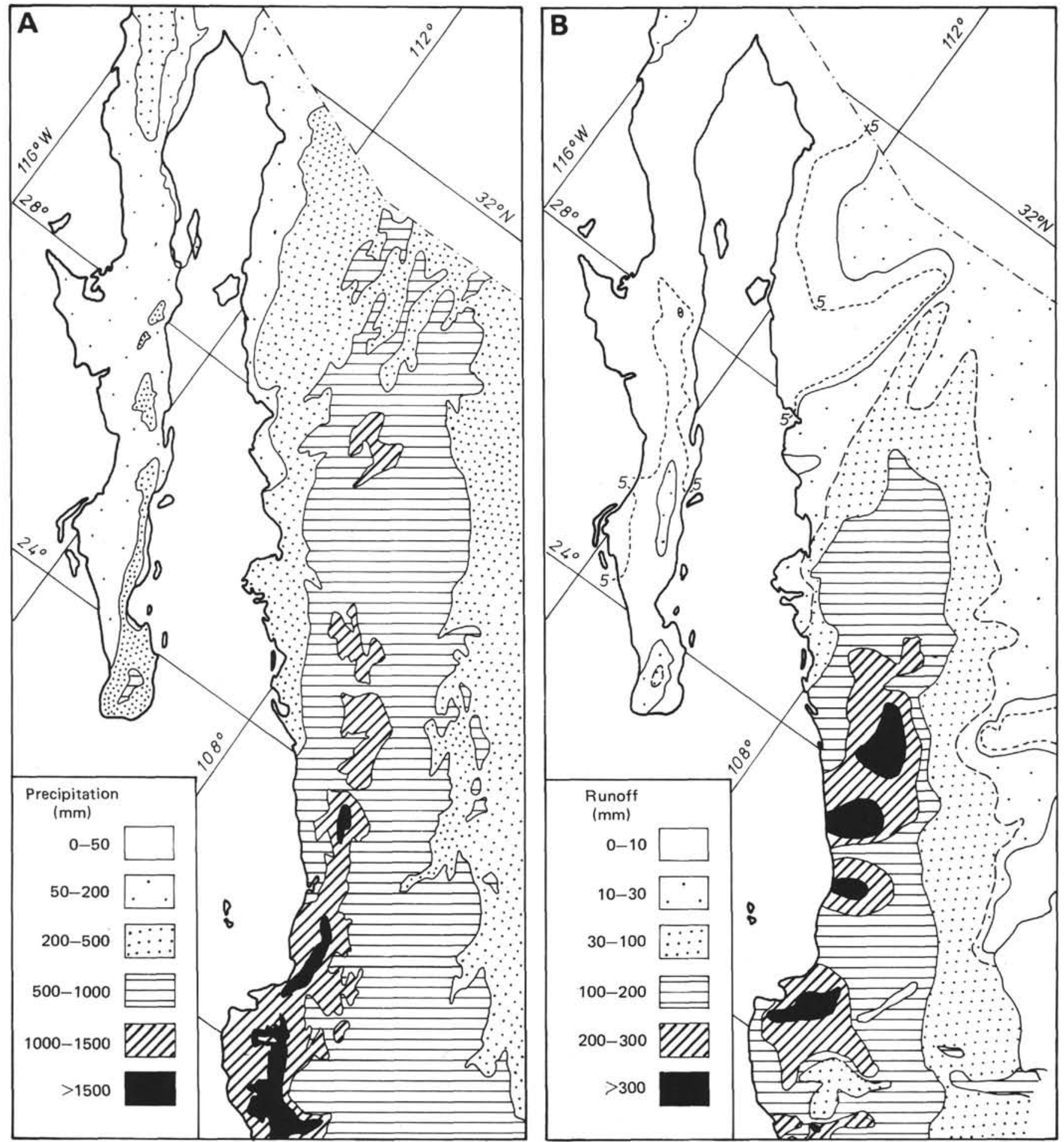

Figure 2. Mean annual precipitation (A) and runoff (B) in the drainage area of the Gulf of California (after Maderey Rascon, 1977).

proper, preventing excessive sediment loss to the open ocean.

5) The areal distribution of surface sediments in the Gulf as a whole has been thoroughly examined by van Andel (1964) and Calvert (1966a,b). The third dimension can be examined from holes drilled on Legs 64 and
65. In addition, sedimentation rates can be derived, leading to more precise interpretations of sedimentary processes prevailing in the Gulf (see, for example, Einsele and Kelts, this volume, Pt. 2).

6) Water content and porosity measurements on samples from the holes drilled make possible a reasonable 


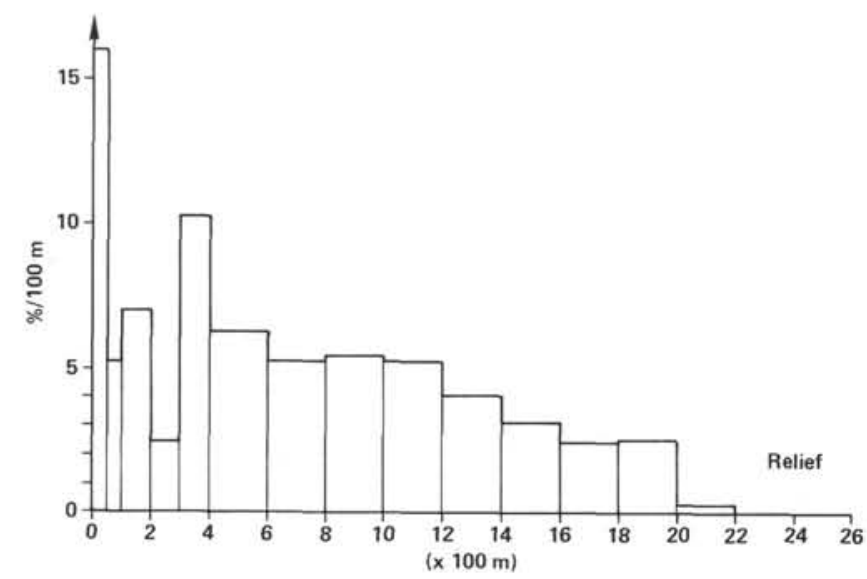

Figure 3. Distribution of relief in approximately 800 quadrangles $(20 \times 20 \mathrm{~km})$ in the total drainage area of the central and southern Gulf (compare Fig. 1).

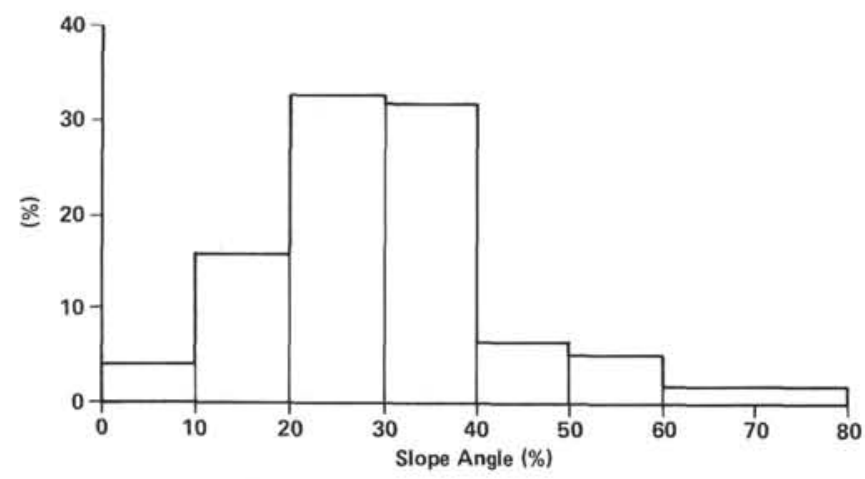

Figure 4. Contribution of areas of different slope angles to the total drainage area of the Río Yaqui.

conversion of wet into dry sediment volume, thus significantly reducing errors encountered in the calculation of sediment budgets in some previous studies.

The shape of the sedimentary basin has been strongly affected by sea-floor-spreading transform faults and subsidence of the passive margins. Thus, the configuration of the sea floor has changed significantly during deposition. This, however, does not present serious problems for the evaluation of the sediment volume trapped in the young postrifting Gulf.

Most of the active transform faults associated with spreading centers in the Gulf no longer affect the land areas. There is some evidence of recent activity along transverse faults of northern Baja California (Allen et al., 1960; Abbott and Gastil, 1979); however, the large, principal drainage area on mainland Mexico with which we are most concerned has probably not been affected.

The effects of the glacial-interglacial period of the Pleistocene appear to have exerted little influence in this region. The lowering of sea level during glacial periods did not significantly affect sedimentation in the central and southern Gulf. A substantial increase of sandy deposits was found only at Site 474, south of the tip of Baja California. Because the Gulf can be characterized as being deep, with relatively narrow continental shelves, sea-level change caused only a moderate shift of the
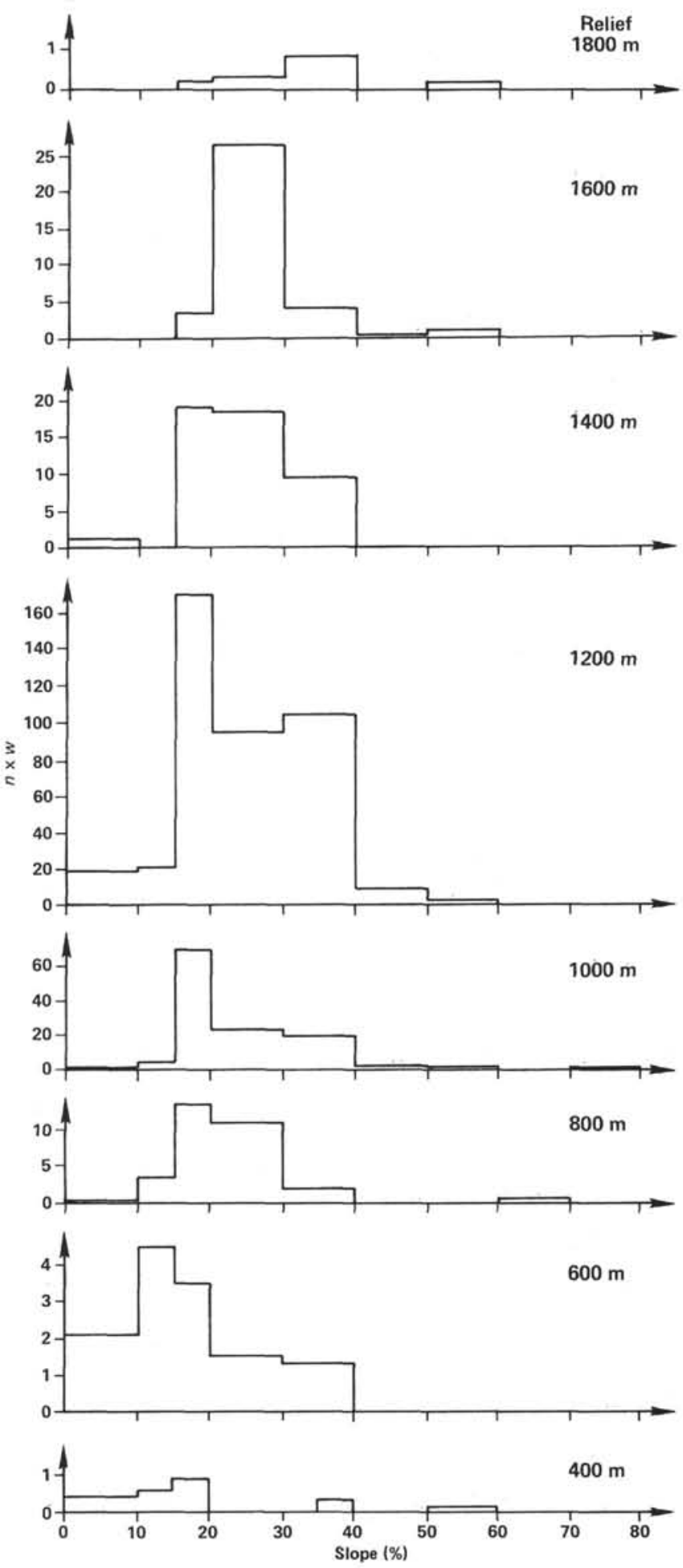

Figure 5. Relationship between the relief of standard quadrangles $(20 \times 20 \mathrm{~km})$ and the distribution of slope angles in the Río Yaqui Basin, as found for different groups of relief. $(n \times w=$ weighted number of slopes.)

coastline toward deeper water (see Curray and Moore, 1964).

\section{Postrifting Gulf}

The success of this study strongly depends on the accumulation area chosen. We must, therefore, exclude 


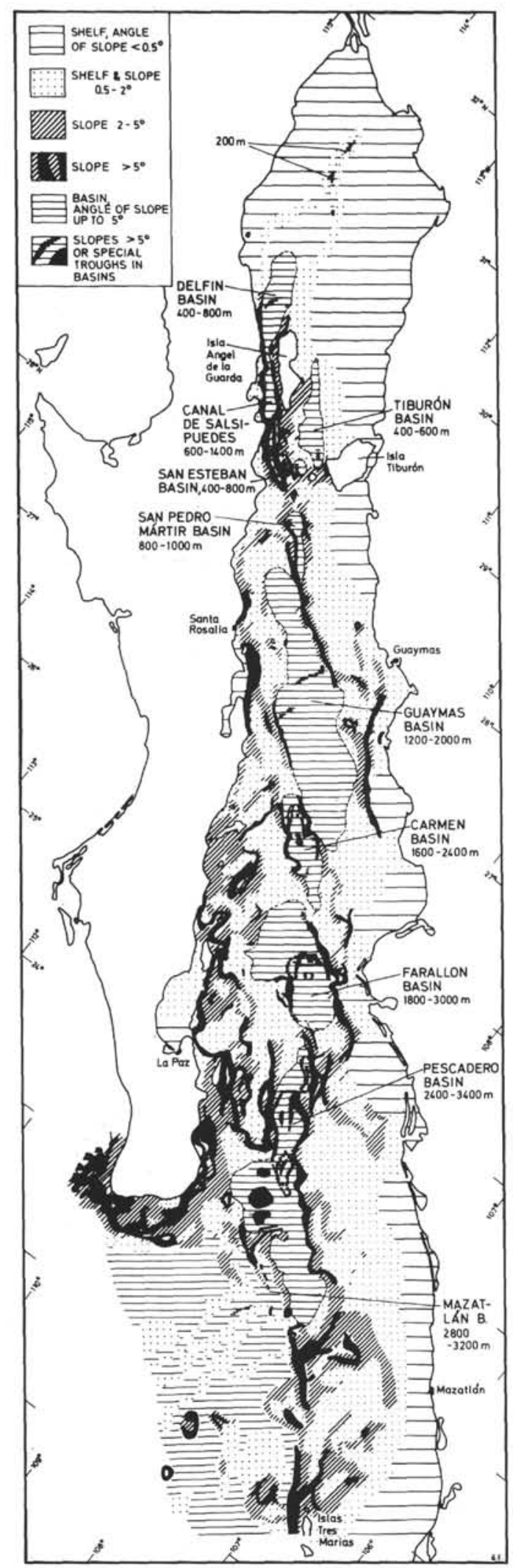

Figure 6. Relief map of the Gulf of California, based on bathymetric map compiled by Bischoff and Niemitz (1980). Note that the Cemarcation of the basins does not correspond with contour lines but with the transition from steeper slopes to flatter bottom. Therefore, the basin floors cover a wide depth range. They also comprise areas with steep slopes as special troughs. those Gulf provinces where data are inadequate-the Colorado River Delta sediment wedge and the region south of Islas Tres Marias. We have chosen the Gulf islands of Tiburón and Angel de la Guarda as the northern terminus of the study area (Fig. 1), for the following reasons:

1) Sedimentation to the north of the islands is almost exclusively from the Colorado River drainage area.

2) The Gulf islands act as a sediment dam which, we assume, effectively traps sediment from the Colorado River.

3) Little seismic control or drilling evidence exists for the northern Gulf to substantiate the exact or even approximate thickness of sediment. The thickness is known to be of the order of 6-7 km in the Salton Trough (Morton, 1977).

4) The area to the south of the Gulf islands represents a more "closed" system, with sediments derived from relatively small and localized drainage areas, mostly but not exclusively along the Sonoran and Sinaloan coast.

The southwestern terminus of the study area is represented by an arbitrary line corresponding to Seismic Line 1-2 of Moore (1973), which crosses the mouth of the Gulf (Fig. 1; Fig. 8, back pocket, this volume, Pt. 2 ). This line appears to approximate the boundary between predominately pelagic sediments and a region which is influenced by the sedimentary processes that predominate within the Gulf-hemipelagic sedimentation. Northeast of this line, seismic evidence suggests that the sediments at the mouth of the Gulf are predominately ponded turbidites (Moore, 1973; Niemitz and Bischoff, 1981). Moreover, large areas of the sea floor in the southern Gulf province are conspicuously devoid of sediment, indicating that the hemipelagic supply typical of the Gulf proper is missing (Fig. 8, isopach map). Sedimentation rates in the literature indicate a range of from $2-1000 \mathrm{~cm} / \mathrm{ky}$. throughout the Gulf (van Andel, 1964; Niemitz, 1977).

The southern boundary of the study area is placed just north of Islas Tres Marias. West of these islands, several seamounts may act as barriers to sediment loss to the south and the Middle America Trench. Relatively low sedimentation rates, ponded turbidites, and extensive, deep sea floor nearly devoid of sediment suggest that little sediment is escaping from the Gulf to the open ocean floor.

\section{Protogulf Shelves}

Prior to the rifting and development of new oceanic crust at spreading centers, a shallow proto-Gulf overlying older, prerifting continental crust existed during late Miocene and early Pliocene time (Karig and Jensky, 1972; Minch and Gastil, 1973; Moore, 1973; Blair, 1978). This proto-Gulf was split apart by the onset of rifting $4 \mathrm{Ma}$. Today, its western and very narrow half is found along the coast of Baja California, either as subaerial plain or buried under relatively thin, younger, postrifting marine sediments. The error in separating postrifting from prerifting sediment on the western 


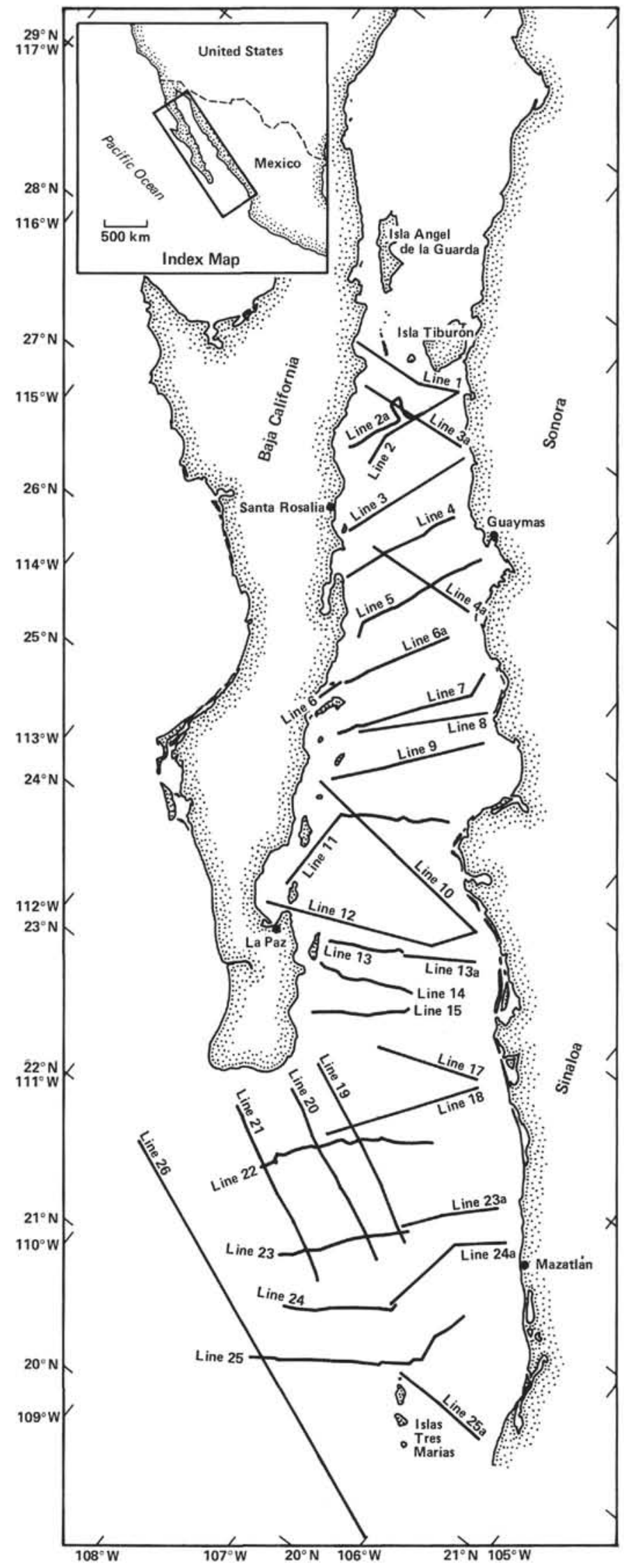

Figure 7. Track lines of seismic surveys in the Gulf of California. The isopach map (Fig. 8) is based on these records. 
shelf, relative to the total sediment volume, is small, for the following reasons (see Fig. 8; isopach map):

1) The area of the western proto-Gulf shelf submerged during the last $4 \mathrm{~m} . \mathrm{y}$. is small.

2) The input of terrigenous material into the Gulf from the drainage area of the peninsula is, at most, a tenth of that contributed from the Mexican mainland (see following discussion of eastern shelf).

3) Only a small part of the sediment input appears to be trapped in shallow water, because flat shelf areas are rare or missing. Although the situation at the tip of Baja California may be somewhat atypical for the central Gulf, the results of Leg 64 (Sites 474-476, this volume) support the suggestion that most of the river load reaching the sea is transported via submarine canyons into deep water (Shepard, 1964). Here, substantial volumes of postrifting, fine-grained sediments are preserved only in small, structurally controlled ponds on the steep slopes. Slope deposits and coastal silts and sands tend to be redeposited by gravity mass transport and to reach the basins of postrifting age (Einsele and Kelts, this volume, Pt. 2).

On the eastern proto-Gulf shelf, however, proto-Gulf and younger (postrifting) sediments appear to exist in large volume. Here, the marginal, older continental crust has subsided significantly because of tectonism and loading by sediments derived from the continent, and a great volume of proto-Gulf sediment is deeply buried under postrifting sediments. Moreover, it is difficult to distinguish between the two sediment bodies with the available data. Therefore, as a first approximation, we will calculate the volume of sediment on postrifting oceanic crust and then attempt an estimate of the postrifting sediment volume present on the eastern proto-Gulf shelf.

The boundary between oceanic $(<4.0 \mathrm{Ma})$ and continental $(>4.0 \mathrm{Ma})$ crust was established using the bathymetry of Bischoff and Niemitz (1980) and seismic profiles which transcend the transition to the shelves (see Fig. 8, isopach map). On the continental shelf and slope, sediments generally thin from the basins toward the shelf break. On the shelf proper, sediments again thicken toward the shoreline.

\section{CALCULATION OF TOTAL VOLUME OF POSTRIFTING SEDIMENTS IN THE GULF OF CALIFORNIA}

\section{Postrifting Sediments on Oceanic Crust}

Postrifting sediments have a maximum age of 4.0 m.y. and rest on oceanic crust or deeply subsided marginal parts of older continental crust that forms part of the present continental slope. The thickness of these sediments was determined from 26 seismic profiles (Fig. 7), the work of Moore (1973) and of IPOD site survey (1975) and pre-existing isopach maps for the southern Gulf (Niemitz and Bischoff, 1981). The results are summarized in a new isopach map (Fig. 8).

The isopach map was derived in a manner similar to that of Moore (1969) for the Southern California Borderland. Units of sediment thickness are given in hundredths of a second two-way travel time. Duplicate thickness data from intersecting seismic lines were consistent, verifying this method of isopach mapping. The isopach contours represent intervals of 10 travel-time units or $0.1 \mathrm{~s}$. For each interval the area represented on the map was determined. Thus, the total area of sediment cover is found as the sum of the areas of all the intervals (Fig. 9). Since any travel-time interval area is the same for any interval coexisting above it, the total area for a travel-time interval was expressed as the sum of that interval plus all interval areas with travel times greater than the particular interval being calculated (Table 2). For example: The total area for the 0.8-0.9-s interval includes the areas of not only the 0.8-0.9-s interval but also the areas of the 0.9-1.0-s, 1.0-1.2-s and 1.2-1.4-s intervals.

An average sonic velocity of $1.5 \mathrm{~km} / \mathrm{s}$ was used to convert travel time to meters of sediment thickness. This value was taken from physical property tests on core samples and acoustic loss of Legs 64 and 65 (this volume) and is in accordance with sonic velocities assumed by Moore (1973).

Volume was calculated for wet sediment in $\mathrm{km}^{3}$ by multiplying the time-interval area by the average thickness of the interval $(75$ or $150 \mathrm{~m})$. This produced a number of slabs of $x$ area and $y$ thickness. The slabs were then summed to obtain the total volume of wet sediment (Table 2).

Wet sediment volume was converted to dry volume by multiplying the wet volume by the ratio of dry to wet sediment corresponding to an average depth for a given slab sub-bottom (Table 2). These dry/wet sediment ratios were taken from Figure 10B, which is based on an average porosity/depth curve for the sediments of the Gulf of California (Einsele, this volume, Pt. 2). The position of the curve between two curves representative of diatomaceous ooze and silty clay can be explained by the intermediate composition of the Gulf sediments and their tendency to lose their diatom content with increasing depth because of dissolution and recrystallization of opaline silica.

The area of the central and southern Gulf containing postrifting oceanic crust is approximately $127,000 \mathrm{~km}^{2}$. Roughly $14,300 \mathrm{~km}^{2}$ or $11 \%$ of this area is sedimentfree and another $43,000 \mathrm{~km}^{2}$ or $34 \%$ shows thicknesses of $0-150$ meters. The remainder of the study area contains postrifting sediments from 150-2100 meters thick. The total volume of postrifting wet sediment is approximately $43,700 \mathrm{~km}^{3}$ (Table 2). Recalculation to dry and solid sediment volume reduces the volume to 12,600 $\mathrm{km}^{3}$. The average sedimentation rate for dry, solid material then is approximately 100 meters in 4.0 m.y., or $2.5 \mathrm{~cm} / \mathrm{ky}$. The error in these calculations is estimated to be $\pm 25 \%$, chiefly owing to inadequate resolution of seismic profiles because of poor recording, interpolation errors in contouring areas lacking adequate seismic control, deviations of the true porosity of sediments from the type curve (Fig. 10A), and other smaller deficiencies of the method used.

\section{Postrifting Sediments on the Proto-Gulf Shelves}

Less certain is the evaluation of the sediment volume on the wide eastern proto-Gulf shelf. Complete strati- 


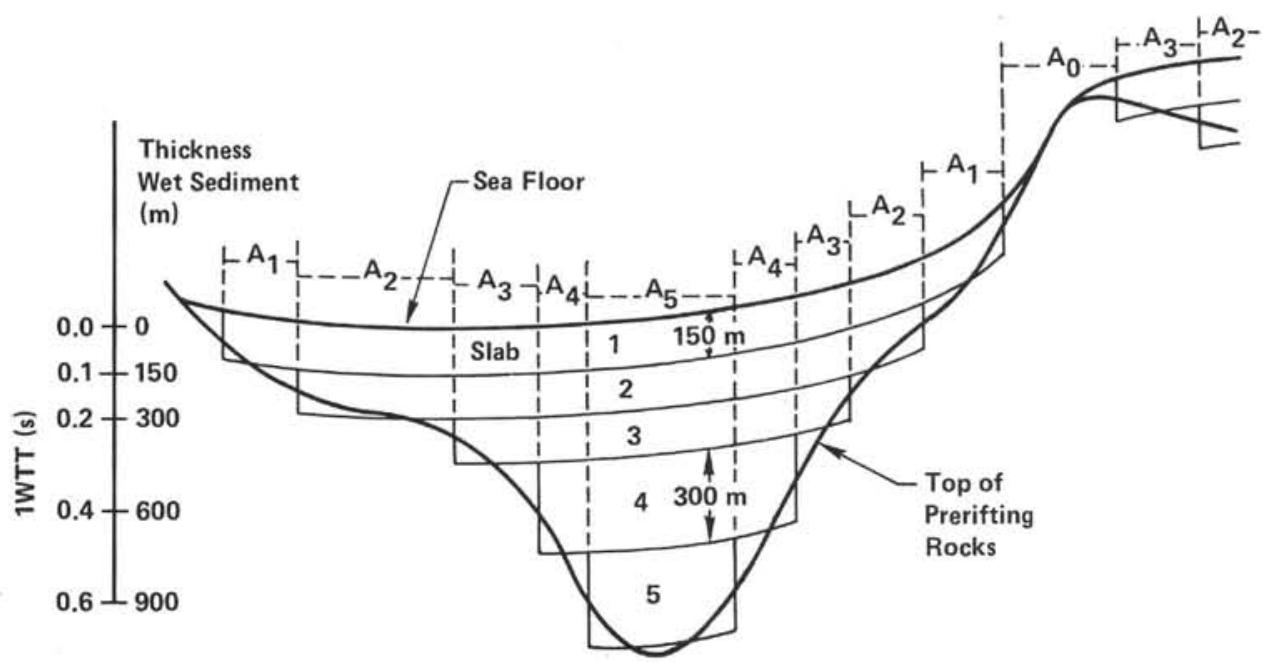

Figure 9. Scheme for the determination of sediment volume (Table 1) from the contour intervals in the isopach map (Fig. 8). $A=$ area of travel-time intervals.

Table 2. Calculation of total wet and dry volume of postrifting sediments in the young central and southern Gulf of California (without proto-Gulf).

\begin{tabular}{|c|c|c|c|c|c|c|}
\hline \multirow[b]{2}{*}{$\begin{array}{l}\text { Seismic Record } \\
\text { Depth Interval } \\
\text { (s) }\end{array}$} & \multirow[b]{2}{*}{$\begin{array}{l}\text { Sediment } \\
\text { Thickness } \\
(\mathrm{m})^{\mathrm{a}}\end{array}$} & \multirow[b]{2}{*}{$\begin{array}{l}\text { Total Area of } \\
\text { Travel Time } \\
\text { Interval }\left(\mathrm{km}^{2}\right)\end{array}$} & \multicolumn{4}{|c|}{ Characteristics of Slab } \\
\hline & & & $\begin{array}{l}\text { Thickness } \\
\text { (m) }\end{array}$ & $\begin{array}{l}\text { Vol. Wet } \\
\text { Sediment } \\
\left(\mathrm{km}^{3}\right)\end{array}$ & $\begin{array}{c}\text { Dry/Wet } \\
\text { Sediment Ratio } \\
\text { for Mean Thickness }\end{array}$ & $\begin{array}{l}\text { Vol. Dry } \\
\text { Sediment } \\
\left(\mathrm{km}^{3}\right)\end{array}$ \\
\hline 0 & 0 & 14,337 & - & - & - & - \\
\hline $0-0.1$ & $0-150$ & 112,552 & 150 & 16,883 & $\begin{array}{l}0.2133 \\
(75 \mathrm{~m})\end{array}$ & 3,601 \\
\hline $0.1-0.2$ & $150-300$ & 69,560 & 150 & 10,434 & $\begin{array}{l}0.2711 \\
(225 \mathrm{~m})\end{array}$ & $2,828.5$ \\
\hline $0.2-0.3$ & $300-450$ & 44,477 & 150 & 6,672 & $\begin{array}{l}0.3227 \\
(375 \mathrm{~m})\end{array}$ & 2,153 \\
\hline $0.3-0.4$ & $450-600$ & 28,699 & 150 & 4,305 & $\begin{array}{l}0.3676 \\
(525 \mathrm{~m})\end{array}$ & 1,582 \\
\hline $0.4-0.5$ & $600-750$ & 16,780 & 150 & 2,617 & $\begin{array}{l}0.4089 \\
(675 \mathrm{~m})\end{array}$ & 1,070 \\
\hline $0.5-0.6$ & $750-900$ & 8,602 & 150 & 1,290 & $\begin{array}{l}0.4449 \\
(825 \mathrm{~m})\end{array}$ & 574 \\
\hline $0.6-0.7$ & $900-1050$ & 4,761 & 150 & 714 & $\begin{array}{l}0.4738 \\
(975 \mathrm{~m})\end{array}$ & 338 \\
\hline $0.7-0.8$ & $1050-1200$ & 2,308 & 150 & 346 & $\begin{array}{l}0.4987 \\
(1125 \mathrm{~m})\end{array}$ & 172.5 \\
\hline $0.8-0.9$ & $1200-1350$ & 1,297 & 150 & 194 & $\begin{array}{l}0.5223 \\
(1257 \mathrm{~m})\end{array}$ & 101.5 \\
\hline $0.9-1.0$ & $1350-1500$ & 566 & 150 & 85 & $\begin{array}{l}0.5404 \\
(1425 \mathrm{~m})\end{array}$ & 46 \\
\hline $1.0-1.2$ & $1500-1800$ & 497 & 300 & 149 & $\begin{array}{l}0.5673 \\
(1650 \mathrm{~m})\end{array}$ & 84.5 \\
\hline $1.2-14$ & $1800-2100$ & 350 & 300 & 105 & $\begin{array}{l}0.6000 \\
(1950 \mathrm{~m})\end{array}$ & 62.5 \\
\hline Totals & & & & 43,694 & & $12,613.5$ \\
\hline
\end{tabular}

graphic information for the shelf sediments is nonexistent, although a number of exploratory wells along the coast of Sonora (Gomez, 1971) have been drilled. The basis for an attempt to calculate the volume of postrifting sediment on the proto-Gulf shelf rests in a limited number of seismic profiles, dredge hauls (Moore, 1973), and two sedimentation rates for Recent shelf sediments (van Andel, 1964; Calvert, 1966). The following speculations on the rate of subsidence of the proto-Gulf shelf may be helpful.

At present, the eastern proto-Gulf shelf and upper slope of the central and southern Gulf occupy an area of roughly $65,000 \mathrm{~km}^{2}$ (see Fig. 8). Because of changes in sea level and because the coastline and shelf have sub- sequently been built up and out, this area must be considered to be a minimum.

From 15 seismic reflection profiles (Moore, 1973) and additional seismic surveys (Bischoff and Niemitz, 1980) across the eastern shelf and slope (Fig. 7), it is evident that the trailing edge of the proto-Gulf crust was subjected to downwarping, downfaulting, and fracturing along extensions of transform faults. The shelf break is often marked by a structural ridge that has dammed postrifting sediments, which commonly dip somewhat eastward away from the Gulf trough (see Figs. 11-15, later). The deposits probably reach a maximum thickness below the upper slope or outer shelf. Near the coast, the postrifting sediments thin, pinching 
A

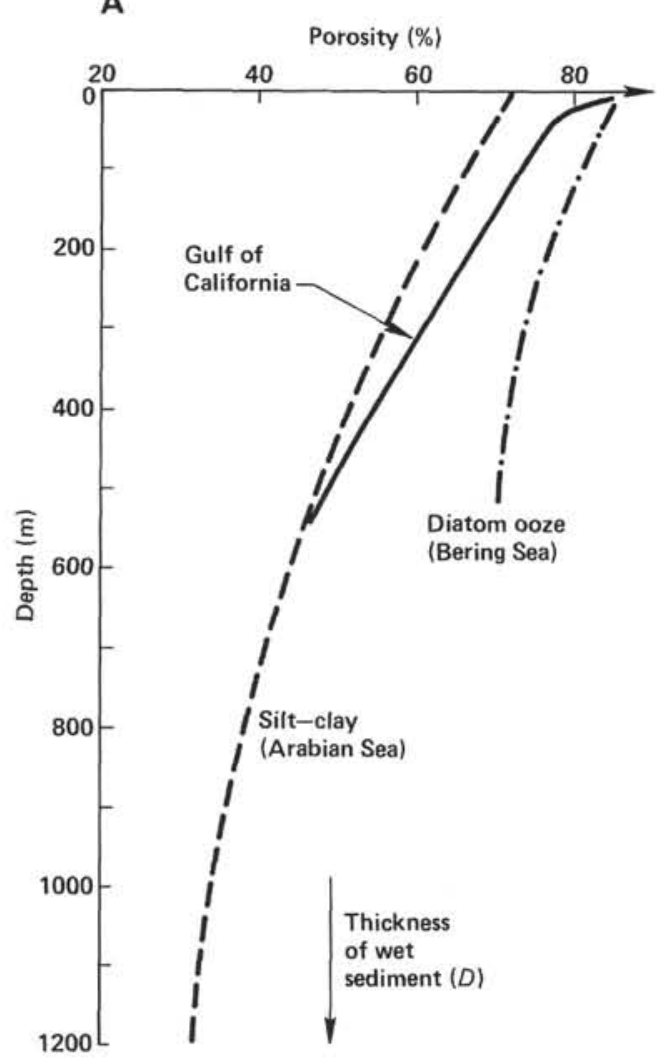

B

Thickness of Solid Matter (Related to D)

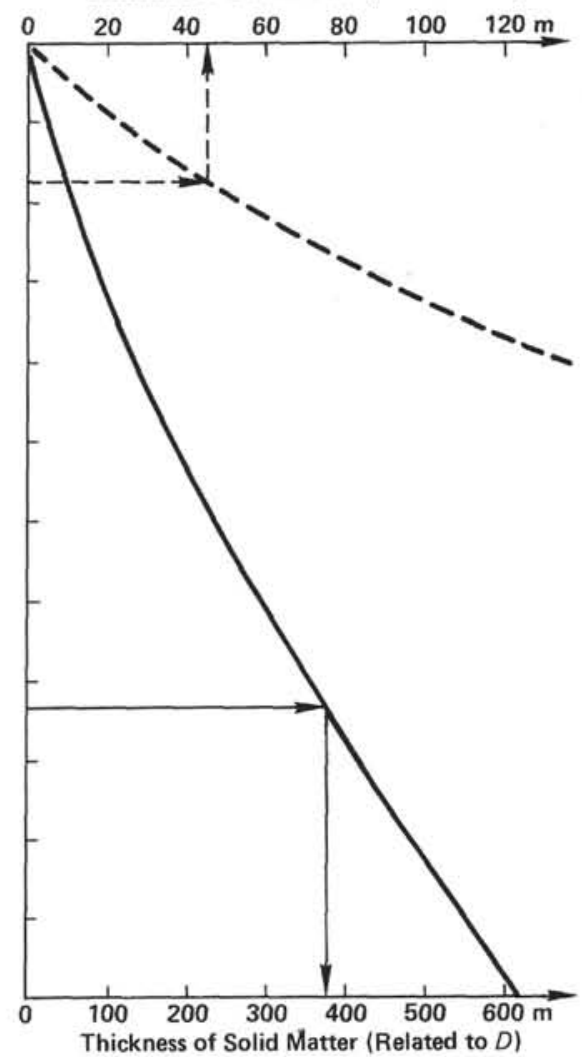

Figure 10. A. Average porosity/depth relationship of basin and slope sediments from the Gulf of California compared to diatomaceous ooze from the Bering Sea (Hamilton, 1976) and silt-clay from the Arabian Sea. B. Conversion of wet to dry sediment thickness in relation to total thickness of sediment below sea floor. Values correspond with the porosity-depth curve for the Gulf of California.

out somewhere below the alluvial plains of the continent.

The prerifting proto-Gulf sediments, as best identified from seismic records in combination with other data (Moore, 1973), are usually more deformed by vertical tectonics. At several locations, inclined strata are found to be truncated by erosion, with younger strata lying unconformably above. The maximum thickness of the younger strata, which may contain some smaller unconformities, ranges between 300 and 750 meters (average $400 \mathrm{~m}$ ). Most of the seismic profiles available for this study, however, show penetration of only 500-800 meters. Therefore, greater sediment thicknesses of (presumably postrifting) sediments may be present but undetectable. We have assumed that the maximum penetration is equal to the maximum thickness of postrifting sediments on the shelf and slope if no major unconformity is present. On all records, the major unconformity occurs at an average depth of 650 meters (range 300-1200 $\mathrm{m}$ ?). Near the coastline, minimum thicknesses of flatlying sediments between 200 and 800 meters (average 380 meters) have been recorded. Here, the differentiation of pre- and postrifting sediments is even more uncertain. In exploration wells, postrifting sediments, including alluvium of less than $4.0 \mathrm{~m}$.y. (late Pliocene and younger), are between 300 and 500 meters thick (Gomez, 1971). Taking all these data into account yields an aver- age thickness of approximately 400-500 meters for postrifting sediment of the shelf and slope.

Sedimentation rates of wet Recent sediments on the eastern shelf and slopes are known only from the upper slope off the Rio Fuerte $(84 \mathrm{~cm} / \mathrm{ky}$., water content related to wet sediment, $63 \%$ ) and from the slope off Mazatlán (12 cm/ky., water content, $70 \%$; van Andel, 1964). The rate off Río Fuerte is high relative to measurements in other parts of the Gulf (Calvert, 1966a; Niemitz and Bischoff, 1981), whereas the rate off Mazatlán is relatively low. If the mean of both values is taken tentatively to be representative, a wet sedimentation rate of $48 \mathrm{~cm} / \mathrm{ky}$. is derived. This translates to a dry, solid-material sedimentation rate of $8 \mathrm{~cm} / \mathrm{ky}$. or 320 meters in 4 m.y. using mass physical property data (Einsele, this volume, Pt. 2).

The Gulf of California is bordered by passive margins. The eastern margin, although strongly influenced by strike-slip movements, may be compared to an early stage of Atlantic-type continental margin development. This suggests that the subsidence histories of the Gulf of California and Atlantic margins are similar. From studies on different parts of the Atlantic-type margin (Watts and Ryan, 1976; Watts and Steckler, 1979; von Rad and Einsele, 1980), it is apparent that during an early stage of ocean basin development, subsidence of the continental margins may be of the order of $100-200 \mathrm{~m} / \mathrm{m} . \mathrm{y}$., 
depending on the extent of local sediment loading and crustal thinning (Kinsman, 1975). If we assume such subsidence values for the proto-Gulf shelf, approximately $400-800$ meters of subsidence is possible in postrifting time; this is totally or partially compensated by sediment accumulation.

Lacking better evidence, we use an average sediment thickness of 400 meters to calculate the volume of postrifting wet and dry sediment on the proto-Gulf shelf and its upper slope. A wet sediment volume of $26,000 \mathrm{~km}^{3}$ results. In order to convert wet volume to dry volume a different porosity curve must be used, since the sediments on the shelf are less fine-grained than basin sediments and contain less biogenic silica and organic matter. Hence, the thickness of dry sediment has been calculated from the average porosity-depth relationship for argillaceous sediment (McCulloh, 1967; Rieke and Chilingarian, 1974). The result is a dry sediment column 230 meters thick, corresponding to an average sedimentation rate of $5.75 \mathrm{~cm} / \mathrm{ky}$. or 2.3 times the rate derived for the deeper, postrifting Gulf floor. For an area of $65,000 \mathrm{~km}^{2}$ then, the volume of dry, solid sediment is $14,950 \mathrm{~km}^{3}$.

This rough estimation suggests that sediments on proto-Gulf crust comprise more than half of the total sediment budget but occupy one-third of the total area.

\section{BUDGET OF SEDIMENT COMPONENTS}

\section{Approaches, Methods, and Constraints}

In addition to the volume of sediment collecting in this narrow, young, ocean basin, the sediment composition in relation to adjacent land areas and biogenic productivity over the basin is of considerable interest. Similar studies have been made or are in progress for some of the large ocean basins (van Andel et al., 1977; Hays and Southam, 1977; Thiede, 1979, Thiede et al., 1981). Little is known, however, about young ocean basins or adjacent seas apart from the budgets for certain components (Calvert, 1966a: silica budget for the Gulf of California; or Ross, Neprochnov, et al., 1978: special studies in the Black Sea). This is due in part to the lack of sufficient information.

The surface sediment composition of the Gulf is relatively well known. The studies of van Andel (1964) and Calvert (1966b) on sediment composition and texture are our chief source of information.

Absent information from Legs 64 and 65, it is reasonable to assume that the surface sediment textures and compositions closely reflect those at depth (site chapters, this volume, Pt. 1; Robinson, Lewis, et al., in press). Thus, except for some diagenetic changes (see later) and alterations in contact zones with doleritic sills, no fundamental vertical changes were observed. The texture of sediments (Gutierrez-Estrada, this volume, Pt. 2) and calcium carbonate and organic carbon content remain relatively constant over all the thicknesses drilled. The same is true of biogenic silica in the upper 200-400 meters of the cores. In sections deeper below the sea floor and especially near doleritic sills, biogenic opal is transformed to chert or contributes to the growth of other authigenic minerals (see site chapters, this volume, Pt. 1).

Van Andel (1964) describes the sediments of the central and southern Gulf as predominately fine-grained with small amounts of deep-water sands of differing origins. Evidence from Leg 64 suggests that the majority of the basin sediments consist of mud turbidites (see site chapters, this volume, Pt. 1, and Einsele and Kelts, this volume, Pt. 2) which are derived from the slopes or prodelta areas of rivers and therefore differ considerably in grain-size distribution and composition. The basin sediments show many minor variations in texture and composition and defy simple classification. The same is true of ponded sediments on slopes or at the mouth of the Gulf on the East Pacific Rise. Therefore, some of the data of van Andel and Calvert had to be modified.

Figures 11-15 represent five cross-sections through the central and southern Gulf of California (see Fig. 1 for locations). The upper sections (A) show the bathymetry according to Bischoff and Niemitz (1980 and this volume, Pt. 2) as well as the thickness of postrifting wet sediment from the isopach map (Fig. 8). Note the lack of thick sediment wedges so prevalent on the flanks of basins in the deepest parts of the basins proper. This is most likely due to rapid sea-floor spreading, which offsets the high sediment accumulation rates that occur simultaneously (Niemitz and Bischoff, 1981). In the middle sections (B) of Figures 11-15 only the thicknesses of wet and dry poreless sediment are plotted (for conversion see Fig. 10B). For calculation of component volumes, dry sediment thicknesses are used. In the lower sections (C) the weight percentages of different components and their variation along the cross-section are listed. Most of these values and their divisions along the cross-sections were taken from the figures published by Calvert (1966a), which represent the composition of surface sediments. Instead of the percentage range given by Calvert (values in parentheses in Figs. 11-15) mean values are used. Where Calvert and van Andel (1964) have plotted only a maximum value (e.g., $\leq 10 \%$ ), a mean value had to be assumed. This was estimated from information on sediments of the same depth range within the Gulf. The data for near-shore and shelf areas, which are based on van Andel's descriptions, are supplemented by assumptions on the contents of organic carbon and opaline silica. Although errors arising from this method may be small for the sediment contribution from the western side of the Gulf, the potential error for the eastern side caused by insufficient data may be as large as that involved in the sediment volume calculation for the shelf areas.

It should be noted that Calvert's "clay" content is calculated from the difference between $100 \%$ and the sum of all directly analyzed components. These "clay contents" are also taken to represent the sediment composition below the sea floor, because they compared well with the sediments from the drill holes mentioned above.

The percentages of each component as well as the sediment types (discussed later) in each cross-section are calculated in the following manner. The cross-sections 
A

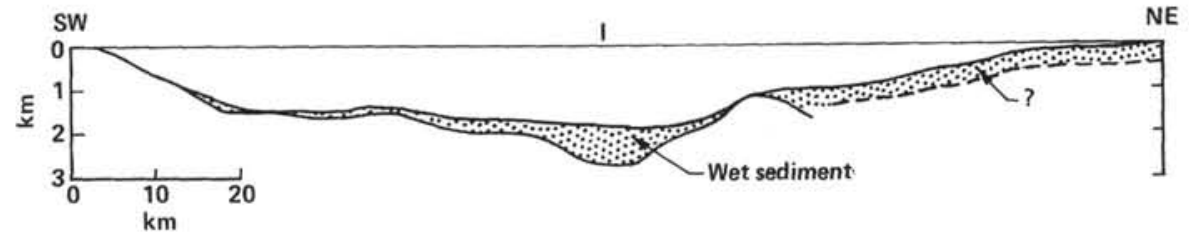

B

C

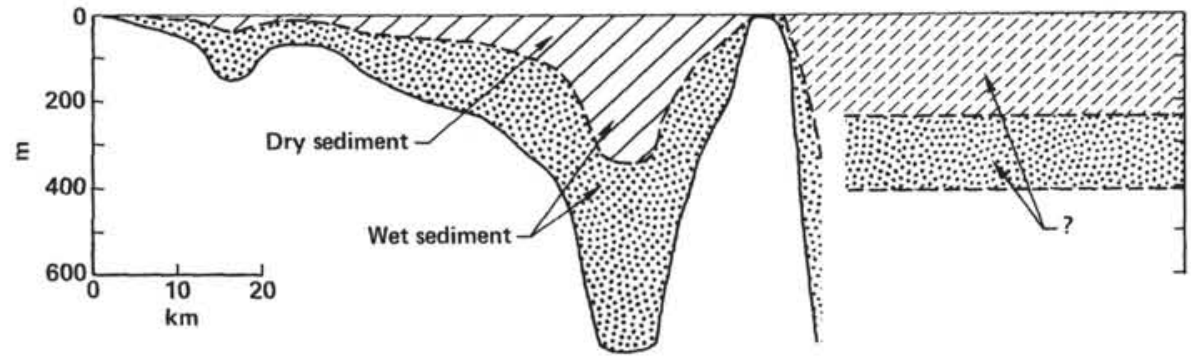

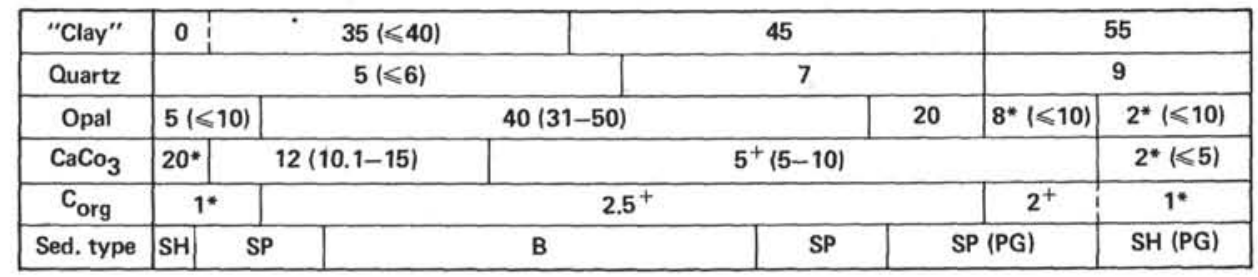

Figure 11. Section across the Gulf north of Guaymas (I in Fig. 1), with thickness of wet and dry sediment. Upper section (A) includes bathymetry and is exaggerated $\times 5$, lower section (B) neglects bathymetry and is exaggerated $\times 50$. Bars below the sections (C) indicate mean percentage (wt. $\%$ ) of main sediment components as described by Calvert (1966) for surface sediments from the same section (Calvert's values are listed in parentheses). (+ represents values based on Leg 64 results, *our own estimations. Sediment types according to the present submarine relief of the Gulf: $\mathrm{SH}=$ shelf, $\mathrm{SP}=$ slope, B = basin; PG signifies corresponding sediment types on older proto-Gulf crust.)

A

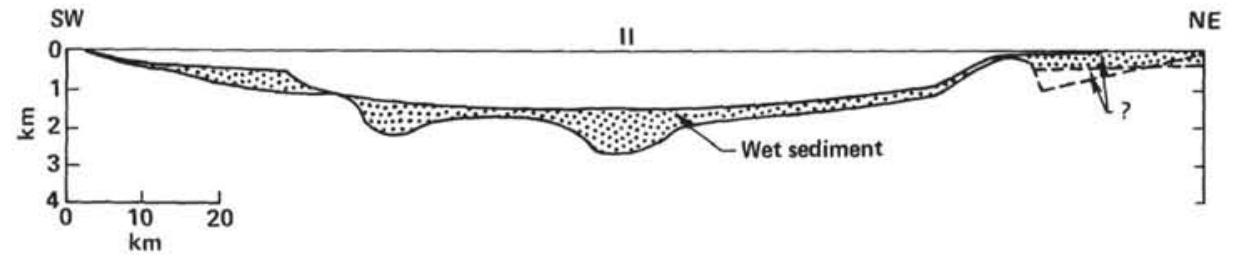

B

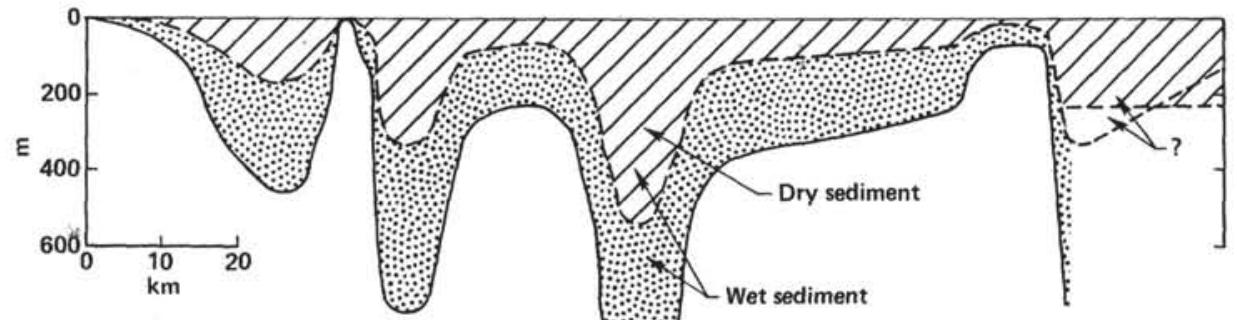

C

\begin{tabular}{|c|c|c|c|c|c|c|c|c|}
\hline “Clay" & 0 & $20^{*}(<40)$ & $35(<40)$ & & $45(41-50)$ & \multicolumn{3}{|c|}{$65(61-70)$} \\
\hline Quartz & \multicolumn{5}{|c|}{$5(\leqslant 6)$} & 7 & \multicolumn{2}{|c|}{$9(8-10)$} \\
\hline Opal & 0 & $5(\leqslant 10)$ & $40(31-5$ & & & (11- & & $3(\leqslant 10)$ \\
\hline $\mathrm{CaCO}_{3}$ & 40 & \multicolumn{2}{|c|}{$12(10-15)$} & & -10) & \multicolumn{3}{|c|}{$2(\leqslant 5)$} \\
\hline$C_{\text {org }}$ & 0 & $1^{*}$ & 2.5 & 4 & $2.5^{+}$ & & $2.5^{+}$ & $1^{*}$ \\
\hline Sed. type & $\mathrm{SH}$ & SP & & B & & & SP & $\mathrm{SH}(\mathrm{PG})$ \\
\hline
\end{tabular}

Figure 12. Section across the Gulf south of Guaymas (II in Fig. 1). (For further explanations see Fig. 11.) 
A

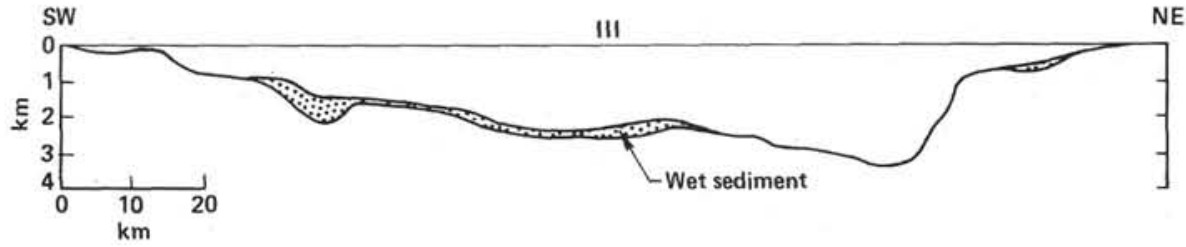

B

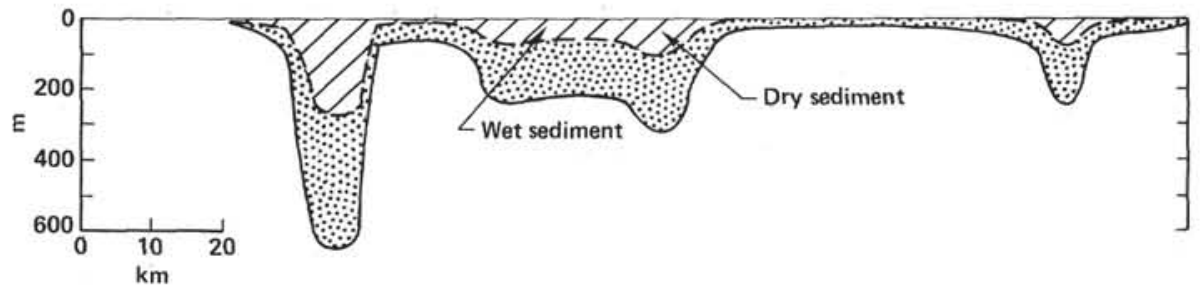

C

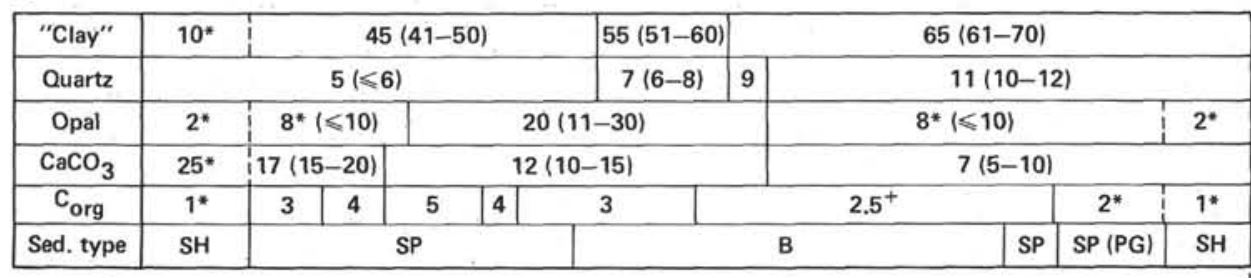

Figure 13. Section across the Gulf off the Río Fuerte Delta (III in Fig. 1). (For further explanations see Fig. 11.)

A

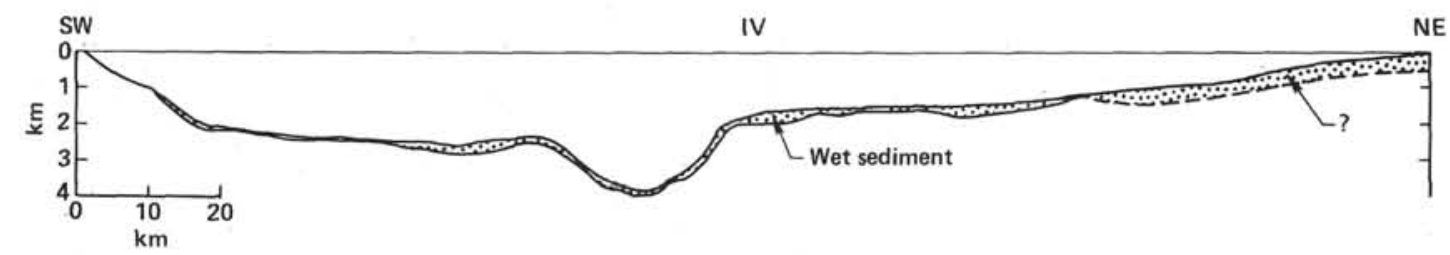

B

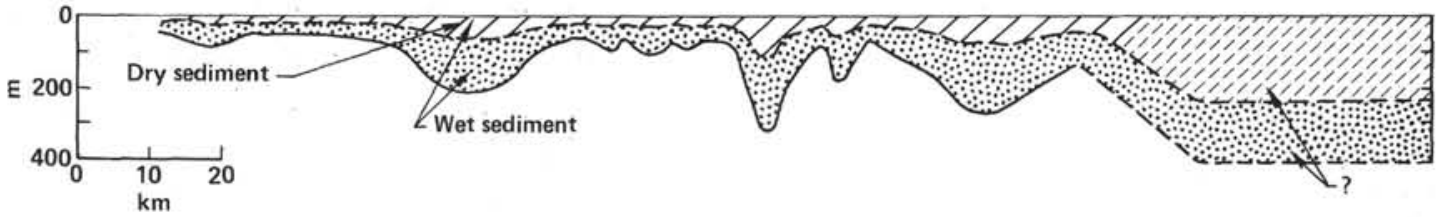

C

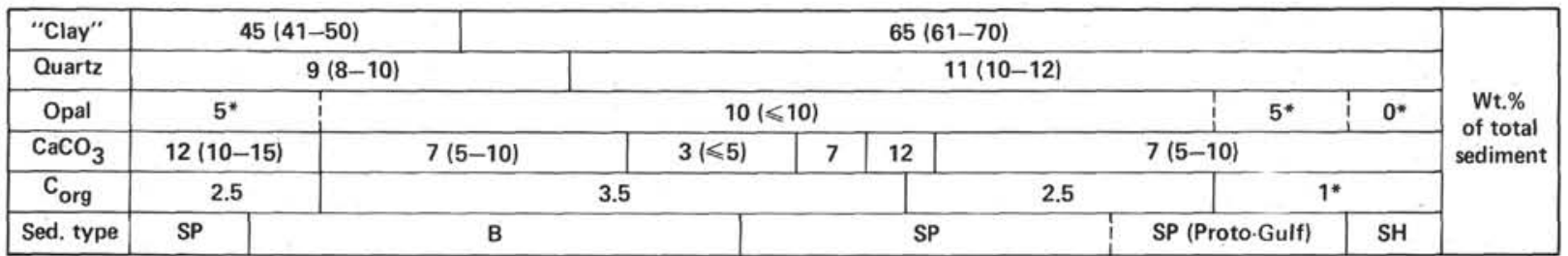

Figure 14. Section across the Gulf south of La Paz (IV in Fig. 1). (For further explanations see Fig. 11.)

are divided into subsections $5 \mathrm{~km}$ long $(L)$. For each subsection, the average thickness $(D)$ of dry sediment is derived from Section B. The total cross-sectional area $\left(A_{T}\right)$ of dry sediment for each transect is then,

$$
A_{T}=L \sum_{1}^{n} D_{n}
$$

where $n$ is the number of subsections in each cross-section. For each component with the variable weight percentage or concentration $\left(C_{n}\right)$ along the cross-sections (Figs. 11-15), the products $C_{n} \bullet L \cdot D_{n}$ for each subsection and the total cross-section

$$
L \sum_{1}^{n} C_{n} D_{n}
$$



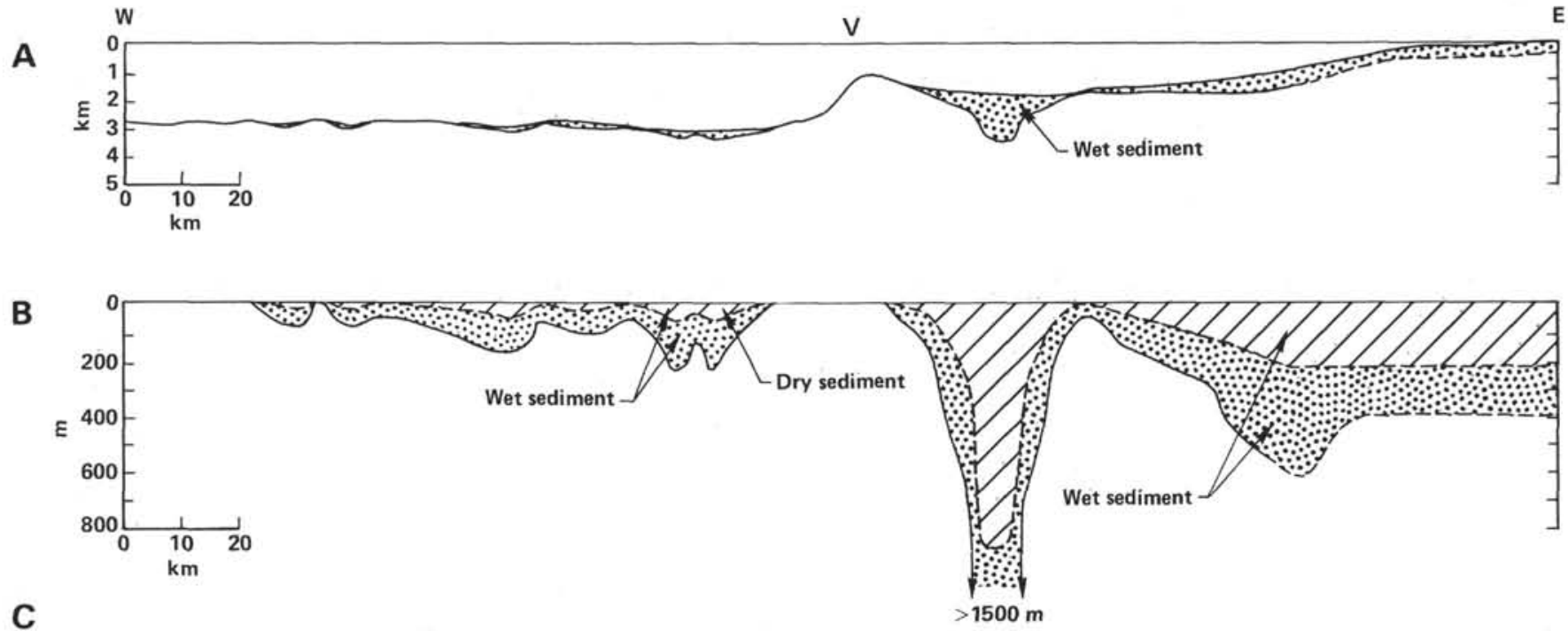

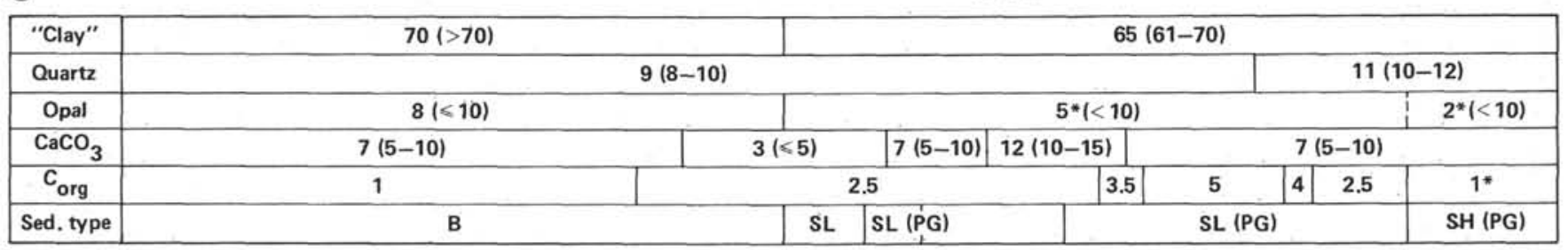

Figure 15. Section from the coast south of Mazatlán across the shelf and slope to the crest of the East Pacific Rise (V in Fig. 1). (For further explanations see Fig. 11.)

are calculated. Thus the percentage $C_{x}$ of the component $x$ in the total sediment section is

$$
C_{x}=\frac{L \sum_{1}^{n} C_{n} D_{n}}{L \sum_{1}^{n} D_{n}}=\frac{\sum_{1}^{n} C_{n} D_{n}}{\sum_{1}^{n} D_{n}}(\%) .
$$

The lowermost line of Figures 11-15 divides all sediments into three principal facies or sediment types, shelf sediments $(\mathrm{SH})$, slope sediments $(S P)$, and basin sediments $(B)$. Differentiation is based solely on the present bathymetry of the sea floor; however, this simple method does not allow a clear separation of the three sediment types. Van Andel has described many more types, yet we feel our subdivision is adequate for this study. Similarly, then, the sum of the cross-sectional areas of these three sediment types $\left(A_{S H}=L \Sigma D_{S H} ; A_{S P}=\right.$ $\left.L \Sigma D_{S P} ; A_{B}=L \Sigma D_{B}\right)$ as well as their percentages $(F)$ of the total area of all subsections $A_{T}$, may be determined, for example, for shelf sediments, as:

$$
F_{S H}=\frac{A_{S H}}{A_{T}} \cdot 100(\%)
$$

This value is the percentage which the shelf sediments represent in the total area of the corresponding crosssection.

\section{Results of Calculations}

The results of these procedures for all five cross-sections are listed separately for the postrifting Gulf and proto-Gulf shelf sediments (Table 3 ). To obtain average values for both parts of the Gulf, each cross-section was weighted according to the area $(A)$ occupied by dry sediment. In total, the area of dry, eastern shelf and upper slope sediments calculated $(59 \%)$ is greater than that of the young Gulf $(41 \%)$ and is in substantial agreement with our estimates on sediment volumes $(54 \%$ and $46 \%$, respectively). Table 4 summarizes the calculations.

An estimate of the percentage of grain sizes (sand, silt, and clay) may be made using the sediment types and their weighted averages (Table 4). The texture of the three sediment types was defined according to van Andel (1964) and the data from Leg 64. In order to get mean values, sometimes data gained by different analytical methods had to be evaluated. Each size fraction contains terrestrial and biogenic material in changing proportions.

\section{Shelf Facies}

Van Andel (1964) has described five different sediment facies for the shelf areas; three of them are predominately sandy and occupy the near-shore and inner shelf zones. The two other subfacies are clayey silts, which are found off the large river deltas and on the deeper outer shelves. Sand:silt:clay ratios of the sandy facies average $60: 25: 15$, about $70 \%$ of the sand fraction consisting of terrigenous material, the rest of biogenic 
Table 3. Composition of central and southern Gulf sediments in five cross-sections and in the total area.

\begin{tabular}{|c|c|c|c|c|c|c|c|c|c|c|c|c|c|c|}
\hline \multirow{3}{*}{$\begin{array}{l}\text { Location of } \\
\text { Cross-Section } \\
\text { (Fig. 1) }\end{array}$} & \multicolumn{7}{|c|}{$\begin{array}{c}\text { Young Gulf } \\
\text { (deep basins and lower slopes) }\end{array}$} & \multicolumn{7}{|c|}{$\begin{array}{l}\text { Postrifting Sediments on Proto-Gulf Crust } \\
\text { (eastern shelf and upper slope) }\end{array}$} \\
\hline & \multirow{2}{*}{$\begin{array}{c}\text { Area } A \\
\text { in Cross- } \\
\text { Section a } \\
\left(\times 10^{6} \mathrm{~m}^{2}\right)\end{array}$} & \multicolumn{6}{|c|}{$\begin{array}{l}\text { Wt. } \% \text { Total } \\
\text { Dry Sediment }\end{array}$} & \multirow{2}{*}{$\begin{array}{c}\text { Area } A \\
\text { in Cross- } \\
\text { Section } \\
\left(\times 10^{6} \mathrm{~m}^{2}\right)\end{array}$} & \multicolumn{6}{|c|}{$\begin{array}{l}\text { Wt. } \% \text { Total } \\
\text { Dry Sediment }\end{array}$} \\
\hline & & "Clay" & Quartz & Opal & $\mathrm{CaCO}_{3}$ & $\mathrm{C}_{\text {org }}$ & $\begin{array}{l}\text { Other } \\
\text { Comp. }\end{array}$ & & "Clay" & Quartz & Opal & $\mathrm{CaCO}_{3}$ & $\mathrm{C}_{\text {org }}$ & $\begin{array}{c}\text { Other } \\
\text { Comp. }\end{array}$ \\
\hline N. Guaymas (I) & 7.0 & 41 & 6.2 & 38 & 5.7 & 2.4 & 6.7 & 9.2 & 54 & 9 & 7 & 4 & 1.8 & 24.2 \\
\hline S. Guaymas (II) & 15.3 & 37 & 5.2 & 30 & 7.4 & 2.7 & 17.7 & 5.2 & 65 & 9 & 3 & 2 & 1 & 20 \\
\hline Off Río Fuerte (III) & 4.9 & 48 & 6.0 & 16 & 13.1 & 3.8 & 11.1 & 0.6 & 65 & 11 & 7 & 7 & 1.8 & 8.2 \\
\hline S. La Paz (IV) & 3.7 & 63 & 10.4 & 9.7 & 7.1 & 3.1 & 6.7 & 9.3 & 65 & 11 & 4 & 7 & 1.3 & 11.7 \\
\hline Mazatlán (V) & 2.4 & 70 & 9.0 & 8 & 6.2 & 1.6 & 5.2 & 23.4 & 65 & 10 & 4 & 9 & 2.6 & 9.4 \\
\hline $\begin{array}{l}\text { Total and } \\
\text { average }\end{array}$ & 33.3 & 45 & 6 & 26 & 8 & $2.8^{\mathrm{e}}$ & 12 & 47.7 & 63 & 10 & 5 & 7 & $2.0^{f}$ & 13 \\
\hline
\end{tabular}

${ }^{a}$ For dry, solid sediment.

b Difference to $100 \%$.

c Thin sediment cover of western half of proto-Gulf crust is included in budget of young Gulf.

$\mathrm{d}$ Weighted average of all cross-sections, values rounded.

e Conversion into organic matter yields $4.8 \%$ (factor 1.7 ).

${ }^{f}$ Conversion into organic matter yields $3.4 \%$ (factor 1.7 ).

Table 4. Major types and texture of sediments in the central and southern Gulf.

\begin{tabular}{|c|c|c|c|c|c|c|c|c|c|c|}
\hline \multirow{3}{*}{$\begin{array}{c}\text { Location } \\
\text { of Cross- } \\
\text { Section } \\
\text { (Fig. 1) }\end{array}$} & \multicolumn{5}{|c|}{$\begin{array}{l}\text { Young Gulf (deep basins and } \\
\text { lower slopes) }\end{array}$} & \multicolumn{5}{|c|}{$\begin{array}{l}\text { Postrifting Sediments on Proto-Gulf Crust } \\
\text { (eastern shelf and upper slope) }\end{array}$} \\
\hline & \multirow{2}{*}{$\begin{array}{l}\text { Area } A \\
\text { in Cross- } \\
\text { Section } \\
\left(\times 10^{6} \mathrm{~m}^{2}\right)\end{array}$} & \multicolumn{3}{|c|}{$\begin{array}{c}\text { Sediment Type } \\
(\%)\end{array}$} & \multirow[b]{2}{*}{ Total $^{\mathrm{d}}$} & \multirow{2}{*}{$\begin{array}{c}\text { Area } A \\
\text { in Cross- } \\
\text { section } \\
\left(\times 10^{6} \mathrm{~m}^{2}\right)\end{array}$} & \multicolumn{3}{|c|}{$\begin{array}{c}\text { Sediment Type } \\
(\%)\end{array}$} & \multirow[b]{2}{*}{ Total $^{\mathrm{d}}$} \\
\hline & & $\begin{array}{l}\text { Shelf } \\
\text { (SH) }\end{array}$ & $\begin{array}{l}\text { Slope } \\
\text { (SP) }\end{array}$ & $\begin{array}{c}\text { Basin } \\
\text { (B) }\end{array}$ & & & $\begin{array}{l}\text { Shelf } \\
(\mathrm{SH})\end{array}$ & $\begin{array}{l}\text { Slope } \\
\text { (SP) }\end{array}$ & $\begin{array}{l}\text { Basin } \\
\text { (B) }\end{array}$ & \\
\hline N. Guaymas (I) & 7.0 & 0.5 & 16 & 83.5 & & 9.2 & 40 & 60 & - & \\
\hline S. Guaymas (II) & 15.3 & - & 17.5 & 82.5 & & 5.2 & 100 & - & - & \\
\hline Off Rio Fuerte (III) & 4.9 & 2 & 61 & 37 & & 0.6 & 17 & 83 & - & \\
\hline S. La Paz (IV) & 3.7 & - & 62 & 38 & & 9.3 & 33 & 67 & - & \\
\hline Mazatlàn (V) & 2.4 & - & - & 100 & & 23.4 & 24 & 38 & 38 & \\
\hline $\begin{array}{l}\text { Total and } \\
\text { average }^{\mathrm{c}}\end{array}$ & 33.3 & 0.4 & 27.3 & 72.3 & & 47.7 & 37 & 44 & 19 & \\
\hline \multicolumn{11}{|l|}{$\begin{array}{l}\text { Average ratios of } \\
\text { sand:silt:clay } \\
\text { (wt. \%) }\end{array}$} \\
\hline Sand & & 33 & 7 & 7 & 7 & & 33 & 7 & 7 & 17 \\
\hline Silt & & 36 & 52 & 52 & 52 & & 36 & 52 & 52 & 46 \\
\hline Clay & & 31 & 41 & 41 & 41 & & 31 & 41 & 41 & 37 \\
\hline
\end{tabular}

particles. The clayey silts contain only a small sand fraction, $(5 \%), 40 \%$ of which is contributed by organisms. The silt content slightly exceeds the clay fraction.

If we tentatively assume that one half of the total shelf facies is built up by the sandy subfacies and the other half by the clayey silts, the ratio of sand:silt:clay is approximately $33: 36: 31$, where about $70 \%$ of the sand fraction is of terrigenous origin.

\section{Slope and Basin Facies}

The slope and basin facies are essentially indistinguishable, according to van Andel. Grain size modes range between 5.5 and $7.75 \phi$ and means range from 6 to more than $8 \phi$ with an average of about $7 \phi$. The finestgrained material is found in the southern end of the Gulf. As previously mentioned, the difficulty in distinguishing basin and slope facies lies in the fact that the slopes deliver mud turbidites to the basins. Leg 64 holes corroborate this assertion. Data provided by GutierriezEstrada (this volume, Pt. 2) suggest that slope and basin sediments have approximately the same texture, with an average sand:silt:clay ratio of 7:52:41. Van Andel observed only $1.1-2.4 \%$ sand in the surface sediments of the basins and slopes; about $60 \%$ of this fraction was found to be of terrigenous origin.

The result of these estimates were also weighted according to the contribution of each sediment type to the total Gulf sediment (Table 4). Table 5 combines the results for the young Gulf and the eastern shelf and upper slopes in order to determine the weighted average of the components and size fractions for the total central and southern Gulf. In summary, $13 \%$ of the postrifting sediments are sands, $48 \%$ silts, and $39 \%$ clay-size material. Roughly one half of the sand fraction is of terrigenous origin, the other half contributed by siliceous and calcareous tests. A large percentage of the silt fraction is contributed by organisms, chiefly diatoms.

\section{Average Sedimentation Rates for Sediment Components}

The central and southern Gulf of California encompasses $192,000 \mathrm{~km}^{2}$ and has accumulated a dry sediment 
Table 5. Composition and texture of sediments in the total central and southern Gulf of California (summary of Tables 3 and 4).

\begin{tabular}{|c|c|c|c|c|c|c|c|c|c|c|}
\hline & \multirow{2}{*}{$\begin{array}{l}\text { Total Area } \\
A \text { of Cross- } \\
\text { sections } \\
\left(\times 10^{6} \mathrm{~m}^{2}\right)\end{array}$} & \multicolumn{6}{|c|}{ Total Dry Sediment (wt.\%) } & \multicolumn{3}{|c|}{ Texture $^{b}$} \\
\hline & & "Clay" & Quartz & Opal & $\mathrm{CaCO}_{3}$ & $\mathrm{C}_{\text {org }}$ & $\begin{array}{l}\text { Other } \\
\text { Comp. }{ }^{c}\end{array}$ & Sand & Silt & Clay \\
\hline Young Gulf & 33.3 & 45 & 6 & 26 & 8 & 2.8 & 12 & 7 & 52 & 41 \\
\hline $\begin{array}{l}\text { Postrifting } \\
\text { sediments on } \\
\text { proto-Gulf crust }\end{array}$ & 47.7 & 63 & 10 & 5 & 7 & 2.0 & 13 & 17 & 46 & 37 \\
\hline Total $^{\mathrm{d}}$ & 81 & 56 & 8 & 14 & 7 & $2.3^{\mathrm{e}}$ & 13 & 13 & 48 & 39 \\
\hline
\end{tabular}

volume of $27,500 \mathrm{~km}^{3} \pm 25 \%$ in the last 4.0 m.y. Thus an average dry sedimentation rate is $3.58 \mathrm{~cm} / \mathrm{ky}$. According to Table 5 , approximately $77 \%$ (by weight) of the sediment is terrigenous, $14 \%$ opal, $7 \%$ carbonate, and $2.3 \%$ organic carbon or $3.9 \%$ organic matter. If we disregard the small differences in specific gravity of the first three components, we derive the following average dry sedimentation rates: terrigenous material, $2.5 \mathrm{~cm} /$ ky.; biogenic silica (opal), $0.5 \mathrm{~cm} / \mathrm{ky}$; biogenic carbonate, $0.25 \mathrm{~cm} / \mathrm{ky}$.

To get a special sedimentation rate for organic matter, its relatively low specific gravity has to be considered. Assuming a specific gravity on the order of 1 $\mathrm{Mg} / \mathrm{m}^{3}$ and an average specific gravity of $1.5 \mathrm{Mg} / \mathrm{m}^{3}$ for the total sediment, the content of organic matter by volume is approximately $9.8 \%$. This yields an average sedimentation rate for organic matter of $0.35 \mathrm{~cm} / \mathrm{ky}$. This rate is equal to the accumulation rate of 3.5 $\mathrm{g} / \mathrm{m}^{2} \cdot \mathrm{y}$. of organic matter.

\section{Remarks on the Calculations}

Prior to a final discussion of the results of our study we should add a few remarks concerning regional tendencies and special components not mentioned above:

1) With the choice of five cross-sections we have tried to encompass typical situations of the Gulf within the constraints of the data available. The two northernmost sections cross the northern and southern parts of the Guaymas Basin, which represent thick deposits that have accumulated since the onset of sea-floor spreading. In contrast, the section off Rio Fuerte crosses the spreading center of the Farallon Basin, which is practically devoid of sediment. The southernmost section off Mazatlán cuts the particularly wide southeastern shelf as well as the East Pacific Rise at the mouth of the Gulf. All five sections reveal the characteristic basin fills below the eastern shelf and the slopes on both sides of the Gulf.

2) The increasing "clay" content from north to south reflects the growing distance from large river mouths as well as the changing climate in the drainage area, whereas the highest values of opal, $\mathrm{CaCO}_{3}$, and organic carbon are found in the central Gulf, where biogenic productivity induced by upwelling is maximized.

3) The results of Tables 3 and 5 show that "clay" with an average percentage of $56 \%$ is the most im- portant component of all Gulf sediments, followed by biogenic components, opal and $\mathrm{CaCO}^{3}$, which together comprise $21 \%$. The component "clay" is neither a grain-size fraction nor a special mineral group. The percentage of the clay-size fraction found for the Gulf $(39 \%$, Table 5$)$ is considerably smaller than the "clay" group as a component.

4) Besides the components listed in Table 3, there remains a relatively small but possibly important percentage of "other components" not included in our calculations. These consist of feldspar, which occurs in quantities similar to quartz, small rock fragments, mica, and heavy minerals. Occasionally, volcanic glass, glauconite, manganese and phosphorite nodules, and crusts and hydrothermal deposits also occur. A small amount of organic matter must be included in "other components" because organic carbon values of Table 3 do not consider the hydrogen, oxygen, and the like that are also present.

\section{DISCUSSION}

\section{Sedimentation Rates in the Central and Southern Gulf of California (accumulation area)}

Clearly, the isopach map (Fig. 8) indicates that average sedimentation rates of the total Gulf do not say anything about the sediment accumulation in a particular area within the Gulf. In reality, rates of dry sediment accumulation vary between zero and possibly as high as 1 $\mathrm{km} / \mathrm{m} . \mathrm{y}$. However, one must consider that a high percentage, if not the majority, of the sediments are redeposited within the basins. The original dispersion of hemipelagic sediment over the total area of the Gulf is much more homogeneous than the final accumulation in the deep basins and in depressions on slopes. Therefore, our average sedimentation rates for the sediment body as a whole and the constituent components can be used to describe general sedimentation processes and organic productivity more effectively than any given atypical rate of a particular basin.

By comparing the discharge of Mexican rivers with that of the Colorado River, van Andel (1964) estimated the annual sediment load of the Mexican rivers to be $1.875 \times 10^{14} \mathrm{~g}$. From our sediment budget for the central and southern Gulf, we need only $1.3 \times 10^{13} \mathrm{~g} / \mathrm{y}$. (using a density of $2.65 \mathrm{~g} / \mathrm{cm}^{3}$ for terrigenous material). 
Although our study area is smaller than van Andel's, this large discrepancy can be attributed mostly to difficulties in estimating the sediment load of rivers.

The sedimentation rate for the total sediment or for the terrigenous components can be compared with those reported for closed basins with large drainage areas and/or source areas of high relief. The drainage area of the Black Sea is approximately 4 times greater than the basin. If the sediment load of the entering rivers (the Danube from the Alps being the most prominent) is spread equally over the total basin area, a sedimentation rate of $14 \mathrm{~cm} / \mathrm{ky}$. results for dry terrigenous material with a $2.5 \mathrm{~g} / \mathrm{cm}^{3}$ specific gravity (calculated from data provided by Ross and Trimonis, 1978).

Biogenic opal and carbonate in the Black Sea contribute $10 \mathrm{~cm} / \mathrm{ky}$. (Degens et al., 1978) wet sediment, which, when converted into dry sediment (1-2 cm/ky.), is considerably higher than that found for the Gulf of California. Our data for the contribution of siliceous material are, however, in the same order of magnitude as those reported for the Monterey Formation (Bramlette, 1946) and the Miocene Mediterranean diatomites (Reading, 1978) as well as for Jurassic radiolarites in the Alps and Apennines (0.3-0.9 cm/ky.; Schlager, 1974).

Our sedimentation rate for biogenic silica (opal) differs, however, from that reported by Calvert (1966b) by a factor of approximately 6 . Using the extremely high sedimentation rate of the central Gulf basins, Calvert determined an annual accumulation of opal as high as $1.5 \times 10^{13} \mathrm{~g}$, although he considered an area of only $30,000 \mathrm{~km}^{2}$. Our average opal content for the total Gulf of $14 \%$ (by weight) in $27,500 \mathrm{~km}^{3}$ or $68.75 \times 10^{18} \mathrm{~g}$ dry sediment in a period of $4.0 \mathrm{~m} . \mathrm{y}$. yields an annual value of only $2.4 \times 10^{12} \mathrm{~g}$. We believe this discrepancy does not cast doubt on Calvert's assertions about the possible sources of silica to the Gulf. For the accumulation of $2.4 \times 10^{12} \mathrm{~g}$ opal, the rivers entering the Gulf deliver, according to Calvert's data, approximately $20 \%$ of the silica supply; the rest has to be provided by the exchange of water masses between the Gulf and the Pacific Ocean.

The average accumulation rate of biogenic carbonate in the Gulf is much lower than in many other environments. This includes deep oceans, where $1-6 \mathrm{~cm} / \mathrm{ky}$. of wet calcareous ooze are deposited. The low percentage of biogenic carbonate in the Gulf sediments is most likely due to dissolution at the sea floor and within the sediments (Matoba, this volume, Pt. 2).

The weighted average for organic carbon $(2.3 \%)$ in Gulf sediments is conspicuously high $(3.9 \%$ organic matter) compared to many other closed or semiclosed basins, for example, the Black Sea (Ross, Neprochnov, et al., 1978). If the average density of solid, dry sediment is assumed to be $2.5 \mathrm{~g} / \mathrm{cm}^{3}$, the organic matter in the postrifting sediment volume of $27,500 \mathrm{~km}^{3}$ amounts to approximately $2.7 \times 10^{18} \mathrm{~g}$.

\section{Comparison of Postrifting Sediments on Oceanic (young Gulf) and Proto-Gulf Crust}

The study area encompasses $127,000 \mathrm{~km}^{2}$ on $0-4$ m.y.-old oceanic crust and $65,000 \mathrm{~km}^{2}$ on older protoGulf crust (essentially the eastern shelf). However, the sediments on the eastern shelf comprise more than one half of the total sediment budget of the central and southern Gulf and have an average sedimentation rate of $5.8 \mathrm{~cm} / \mathrm{ky}$. (dry, solid material) in contrast to $2.5 \mathrm{~cm}$ / $\mathrm{ky}$. in the deeper young Gulf. This result of our calculations seems to be surprising, considering the relatively high percentage of terrigenous material $(63 \%$, Table 5$)$ in the sediments of the young Gulf as well as the sediments transported from shallow to deep water by the action of turbidity currents. This discrepancy may be explained as follows:

1) Most of the terrigenous material is derived from eastern source areas and a great part of this material is trapped by structural ridges, as discussed earlier; see also Moore (1973).

2) Rifting and the onset of ocean floor spreading is accompanied by continuing subsidence of the continental margin (proto-Gulf), which makes possible the accumulation of thick shelf sediments.

3) The present extent of the young, deep Gulf does not correspond with the average area the Gulf has encompassed during the last $4 \mathrm{~m} . \mathrm{y}$. It is approximately twice as large, since the Gulf has grown by ocean spreading from zero to its present size. Consequently, on an average the young Gulf provided somewhat less area for sediment accumulation than the eastern shelf. For that reason, the contribution of the three principal sediment types to the total sediments of the eastern shelf (proto-Gulf) and the young Gulf (Table 4) should be further discussed. In the course of time after ocean spreading begins, one can expect that on proto-Gulf crust, the percentage of shelf sediments will tend to increase at the expense of basin and slope sediments, because structural sediment traps will soon be filled up. On oceanic crust, in contrast, the contribution of basin sediments to the total sediment body will grow because of continuing ocean spreading. Thus the data listed in Table 4 are valid only for postrifting sediments 0 to 4 m.y. old. In the future, the growing, deep Gulf will collect a higher percentage of the total sediment accumulated on both oceanic and proto-Gulf crust.

A difficult, but probably minor problem is the contribution of doleritic sills to the sediment volume. At the spreading centers, sills are injected into wet sediments, causing dewatering and other diagenetic changes (Einsele et al., 1980; Gieskes et al., "Hydrothermal Synthesis," this volume, Pt. 2). Seismic lines crossing these areas are difficult to interpret, because the contacts between soft overlying sediments, sills, and their accompanying indurated sediments are often hummocky and consequently difficult to resolve. The tops of zones of intercalated doleritic sills and sediments are regarded as the base of the sediment section. Hence the intercalated sediments are neglected in our sediment budget. However, a comparison of spreading and sedimentation rates demonstrates that the sill-sediment zones above oceanic crust can have only limited thickness (order of magnitude of $200 \mathrm{~m}$; see Einsele, this volume, Pt. 2). Furthermore, the extent of sills in spreading basins other than the Guaymas is unknown. We suspect that the sill-sediment zones constitute a small part of the spreading centers and that their consequent effect on the sediment budget is probably small. 


\section{Denudation Rate of the Drainage Area}

After the average sedimentation rates for terrigenous material deposited in the central and southern Gulf in the last $4.0 \mathrm{~m}$.y. are calculated, it is possible to calculate the average denudation rate for the drainage area of the Mexican continent and Baja California which contributes this material. If we use the accumulation rate in the Gulf and the ratio of the surface area of the Gulf $(192,000$ $\left.\mathrm{km}^{2}\right)$ to the surface area of the source area $(271,500$ $\mathrm{km}^{2}$; see Fig. 1 and Table 1), a denudation rate of approximately $2.0 \mathrm{~cm} / \mathrm{ky}$. results. This rate represents mechanical (not chemical) denudation of solid rocks with a density of $2.5 \mathrm{Mg} / \mathrm{m}^{3}$, as was assumed for dry Gulf sediments. According to Ahnert (1970) and Garrels and Mackenzie (1971), rivers in regions of arid or semiarid climate carry, however, only a small percentage of their total load in solution. The average gross yield of dissolved solids for the Colorado River, for example, is approximately $3 \%$ of suspended load (Holeman, 1968; Durum et al., 1960).

Our denudation rate of $2.0 \mathrm{~cm} / \mathrm{ky}$. for the drainage area of the central and southern Gulf is, of course, a mean value which has, like the average sedimentation rate of the Gulf, little significance for a small region within the total area. In the lowlands near the coast, deposition of alluvium over the long term can be expected, whereas higher rates of erosion will prevail in the highlands because of the strong relief. In the river basin of the Little Colorado in Arizona, Rice (1980) determined from geologic evidence a mean long-term denudational lowering of $4.8 \mathrm{~cm} / \mathrm{ky}$. but found enormous variations according to the nature of the outcropping rocks. From sediment discharge he found present denudation rates to be lower than $0.2 \mathrm{~cm} / \mathrm{ky}$. over large areas, whereas the trunk river was cutting down at the rate of $9.5 \mathrm{~cm} / \mathrm{ky}$. These facts support the assertions of some workers (for example, Langbein and Schumm, 1958) that sediment yield per unit area decreases with increasing size of drainage area. For this reason, only drainage areas of similar size and character should be compared. Nevertheless, when these comparisons of similar relief, sine of slope, or climate are made, our mean denudation rate of $2.0 \mathrm{~cm} / \mathrm{ky}$. appears to be low.

Present-day denudation rates associated with Quaternary (1 m.y.) sedimentation in the Southern California Borderland (Moore, 1969) average $12 \mathrm{~cm} / \mathrm{ky}$. from an area of $31,000 \mathrm{~km}^{2}$. This rate is six times higher than our value, while the drainage area is one-eighth of our study area. Ahnert (1970) presents further present-day data for drainage areas comparable to this study:

\begin{tabular}{cccc}
\hline & Drainage \\
Area & Mean Relief & $\begin{array}{c}\text { Mean Sine } \\
\text { of Slope }\end{array}$ & $\begin{array}{c}\text { Mean } \\
\text { Denudation } \\
\text { Rate } \\
\text { (cm/ky.) }\end{array}$ \\
\hline $\begin{array}{c}\text { Green River, Utah } \\
\begin{array}{c}\text { Colorado River } \\
\text { above Cisco, Utah }\end{array}\end{array}$ & $1044 \mathrm{~m}$ & 0.113 & 8.2 \\
$\begin{array}{c}\text { Drainage area, } \\
\text { this study }\end{array}$ & $820 \mathrm{~m}$ & 0.134 & 12.4 \\
\hline
\end{tabular}

The few data presented here show mean denudation rates which are greater than our value by a factor of 4 to 6. Our low value appears to confirm the opinion of some workers (Douglas, 1967; Hadley, 1974) that geological, that is, long-term denudation rates are generally much lower than present-day rates, which are often strongly affected by man's activity.

The low denudation rate calculated here also may be due to the following circumstances:

1) Under arid conditions, large amounts of coarse residuals are produced which are not readily transported to the base level (Garner, 1959). The drainage area as outlined here also encompasses lowlands of considerable extent, especially in the coastal zone of the Rios Sonora, Yaqui, Mayo, and Fuerte. Here, in postrifting time, continental Pliocene and Quaternary sediments of considerable thickness have accumulated. These sediments are not included in our sediment budget. Consequently the eroded masses are greater and denudation is restricted to a smaller area, possibly two-thirds of the total area. Hence, the denudation rate in the proper region of mass waste may be higher than our calculated mean by a factor of 2 .

2) The resistance of the dominant intermediate-toacidic volcanic rocks to weathering and denudation is probably greater than that of other lithologies. Thus the lowering of the land surface may be inhibited and less material per unit area eroded and transported to the Gulf basin.

Other factors may contribute. When sea-floor spreading began, the bathymetry of the Gulf may have allowed greater sediment loss to the open ocean than appears to be occurring at present. Climatic changes during Pleistocene time, with repeated changes in sea level, may have reduced denudation on land and, at the same time, enabled a greater sediment loss to deep water. Young uplift of neighboring land masses may have intensified relief. Unfortunately, a quantitative evaluation of these factors is not possible at this time.

\section{CONCLUSIONS}

The Gulf of California represents a young, deep, ocean basin between high mountain ranges; it was generated by the divergence of continents (Moore and Buffington, 1968). Thiede (1978) describes different types of such young oceanic basins, including the Gulf of California and qualitatively characterizes sediment control by the adjacent land areas, the configuration of the basin, and its connection with a large ocean.

In this study we have made an attempt to quantify the sedimentary processes in a narrow ocean basin and, from the results, to deduce a denudation rate for the drainage areas. This approach was made possible by a new isopach map for postrifting sediments and by early drilling results from DSDP Legs 64 and 65 in the central and southern Gulf of California that provided previously missing information on vertical sediment variation. Although the northern Gulf and the influence of the Colorado River could be excluded, a sediment budget of the remaining parts of the Gulf turned out to be rather difficult. Sediment thickness is chiefly controlled by structure and the resulting complicated bathymetry; 
continuing ocean spreading has strongly affected the depositional area of the young Gulf. During the early stages of rifting, the different spreading centers within the Gulf had not yet fully developed the present Gulf basins, which are now acting as sediment traps. Therefore, at the wide mouth of the Gulf, some sediment may have been lost to the Pacific Ocean. Lack of sufficient information about postrifting sediments on proto-Gulf crust (chiefly on the mainland shelf) inhibits any wellfounded estimate of sediment volume and composition for this part of the Gulf sediments. Because of these difficulties, our data on sediment volumes, accumulation rates, and the deduced average denudation rate for the drainage areas tend to represent minimum values.

In the entire Gulf, i.e., on young oceanic crust (deep basins) and on proto-Gulf crust (shelves), shelf sediments comprise approximately $22 \%$ and slope sediments $37 \%$ of the total sediment body. Hence, in this stage of opening of a young ocean, basin sediments $(41 \%)$ do not yet dominate. The unexpectedly high proportion of shelf sediments in a young narrow basin is caused by the combination of rapidly subsiding continental margin and structurally controlled sediment trapping.

Despite the neighboring high mountain ranges and a mainly arid to semiarid climate in the drainage areas, terrigenous sand is only a minor constituent of the Gulf sediments. It contributes about one half of the total sand fraction which comprises $13 \%$ of the sediment body; the other half originates from siliceous and calcareous tests. A great part of the sandy and coarsergrained residuals is already deposited as alluvial fans on land. For that reason, sandy turbidites are surprisingly rare in the basin sediments. They are replaced by mud turbidites that transport the predominating silts $(48 \%$ of the total sediment) of terrigenous and biogenic origin from delta fronts and slopes into deep water (Einsele and Kelts, this volume, Pt. 2). As the climate becomes increasingly humid toward the south, the clay fraction (39\% of the total sediment body) becomes the most important constituent.

The high production and preservation of biogenic components (approximately $25 \%$, by weight, of the total sediment) is made possible by the wide opening of the Gulf to the central Pacific, the large exchange of water masses, and the influence of nutrient-rich waters entering the Gulf and upwelling over the central basins (van Andel, 1964; Calvert, 1966a,b; Thiede, 1978). Under the influence of upwelling, biogenic silica $(14 \%)$ is twice as abundant as carbonate $(7 \%)$, which appears to be strongly reduced by dissolution. The contributions of organic carbon $(2.3 \%)$ or organic matter $(3.9 \%)$ to the total sediment of all types are remarkably high. The input of terrigenous material and the accumulation of biogenic silica, as averaged over the 4 m.y. of post-rifting time, are, however, much less than previously assumed for the present-day situation.

The average sedimentation rate of $3.6 \mathrm{~cm} / \mathrm{ky}$. (dry, solid material) for all Gulf sediments appears to be rather low in view of the high relief of the drainage area. This value is, however, like the rates for individual sedi- ment components, related to the present configuration of the Gulf and its 4-m.y.-old sediments. If it were related to a 2-m.y.-old postrifting stage, at least the rates for terrigenous material would be higher, because the area of the Gulf was smaller. Therefore, it is realistic that the sedimentation rate for the postrifting sediments on proto-Gulf crust which was not affected by ocean spreading was found to be considerably higher $(5.8 \mathrm{~cm} /$ ky.) than that of the young Gulf $(2.5 \mathrm{~cm} / \mathrm{ky}$.). Taking spreading into account, the mean rate for the 4-m.y.-old oceanic Gulf floor is $5 \mathrm{~cm} / \mathrm{ky}$. In reality, sedimentation rates vary from practically zero on bathymetric highs to at least $100 \mathrm{~cm} / \mathrm{ky}$. (e.g., in the Guaymas Basin). The relatively low mean denudation rate $(2 \mathrm{~cm} / \mathrm{ky}$.) in the drainage area of the central and southern Gulf is derived from the sediment accumulation in the Gulf during the last 4 m.y. Locally, high relief and climate transitional between arid conditions in the northwest and humid conditions in the southeast certainly lead to a stronger denudation, for a considerable part of the weathering products is also stored in the lowlands of the drainage area.

\section{ACKNOWLEDGMENTS}

This study has greatly benefitted from the cooperation of the Leg 64 scientific and technical teams on board Glomar Challenger; especially K. Kelts was helpful in different ways. S. Calvert (Vancouver) and $\mathrm{J}$. Thiede (Oslo) critically read the manuscript and made many valuable suggestions. G. Einsele received financial support from the German Research Foundation; it is gratefully acknowledged.

\section{REFERENCES}

Abbott, P. L., and Gastil, R. G. (Eds.), 1979. Baja California Geology: Field Guides and Papers. Geol. Soc. Am. Ann. Meeting, 1979: San Diego (San Diego State Univ.).

Ahnert, F., 1970. Functional relationships between denudation, relief, and uplift in large mid-latitude drainage basins. Am. J. Sci., 268:243-263.

Allen, C. R., Silver, L. T., and Stehli, F. G., 1960. Agua Blanca fault-a major transverse structure of northern Baja California, Mexico. Geol. Soc. Am. Bull., 71:457-482.

Allison, E. C., 1964. Geology of areas bordering Gulf of California. In van Andel, Tj. H., and Shor, G. G., Jr. (Eds.), Marine Geology of the Gulf of California: A Symposium. Am. Assoc. Pet. Geol. Mem. 3: Tulsa (AAPG), 3-29.

Bischoff, J. L., and Niemitz, J. W., 1980. Bathymetric Maps of the Gulf of California. Geol. Surv. Misc. Investig. Ser. (U.S.), Map I-1244, 4 plates.

Blair, W. N., 1978, Gulf of California in Lake Mead area of Arizona and Nevada during late Miocene time. Bull. Am. Assoc. Pet. Geol., 62:1159-1170.

Blatt, H., Middleton, G., and Murray, R., 1980. Origin of Sedimentary Rocks (2nd. ed.): Englewood Cliffs, N.J. (Prentice-Hall).

Bramlette, M. N., 1946. The Monterey Formation of California and the Origin of Its Siliceous Rock. U.S. Geol. Surv. Prof. Paper 212.

Butzer, K. W., 1976. Geomorphology from the Earth: New York (Harper and Row).

Byrne, J. V., and Emery, K. O., 1960. Sediments of the Gulf of California. Geol. Soc. Am. Bull., 71:983-1010.

Calvert, S. E., 1966a. Accumulation of diatomaceous silica in the sediments of the Gulf of California. Geol. Soc. Am. Bull., 77: 569-596.

1966b. Origin of diatom-rich, varved sediments from the Gulf of California. J. Geol., 74:546-565.

Curray, J. R., and Moore, D. G., 1964. Pleistocene deltaic progradation of continental terrace, Costa de Nayarit, Mexico. In van Andel, Tj. H., and Shor, G. G. (Eds.), Marine Geology of the Gulf of California: A Symposium. Am. Ass. Pet. Geol. Mem. 3: Tulsa (AAPG), 193-215. 
1971. Growth of the Bengal deep-sea fan and denudation in the Himalayas. Geol. Soc. Am. Bull., 82:563-572.

Degens, E. T., Stoffers, P., Golubić, S., and Dickman, M. D., 1978. Varve chronology: Estimated rates of sedimentation in the Black Sea deep basin. In Ross, D. A., Neprochnov, Y. P., et al., Init. Repts. DSDP , 42, Pt. 2: Washington (U.S. Govt. Printing Office), 499-508.

Demant, A., and Robin, C., 1975. Las fases del vulcanismo en México: una sintesis en relación con la evolución geodinámica desde el Cretácico. Rev. Inst. Geol. (Univ. Nac. Auton. Mex.), 75(1):70-83.

Douglas, I., 1967. Man, vegetation and the sediment yield of rivers. Nature, 215:925-928.

Dunbier, R., 1968. The Sonoran Desert: Tucson (Univ. Arizona Press).

Durum, W. H., Heidel, S. G., and Tison, L. J., 1960. World-wide runoff of dissolved solids. Internat. Assoc. Sci. Hydrol. Publ. 51: Gentbrugge (IASH), pp. 618-628.

Einsele, G., Gieskes, J. M., Curray, J. R., Moore, D. M., Aguayo, E., et al., 1980. Intrusion of basaltic sills into highly porous sediments, and resulting hydrothermal activity. Nature, 283:441-445.

Flint, R.-F., 1971. Glacial and Quaternary Geology: New York (Wiley).

Garner, H. F., 1959. Stratigraphic-sedimentary significance of contemporary climate and relief in four regions of the Andes mountains. Geol. Soc. Am. Bull., 70:1327-1368.

Garrels, R. M., and Mackenzie, F. T., 1971. Evolution of Sedimentary Rocks: New York (Norton).

Gastil, G., and Krummenacher, D., 1977. Reconnaissance geology of coastal Sonora. Geol. Soc. Am. Bull., 88:189-198.

Gastil, R. G., Phillips, R. P., and Allison, E. C., 1975. Reconnaissance Geology of the State of Baja California. Geol. Soc. Am. Mem. 140.

Gierloff-Emden, H. G., 1964. Die Halbinsel Baja California, ein Entwicklungsgebiet Mexikos. Mitt. Geog. Ges. Hamburg, 55. 1970. Mexico, eine Landeskunde: Berlin (De Gruyter).

Gomez, M., 1971. Sobre la presencia de estratos marinos del Mioceno en el Estado de Sonora, México. Rev. Inst. Mex. Pet., 3: 77-78.

Hadley, R. F., 1974. Sediment yield and land use in southwest United States. Int. Ass. Sci. Hydrol. Publ. 113: Gentbrugge (IASH), pp. 96-98.

Hamilton, E. L., 1976. Variations of density and porosity with depth in deep-sea sediments. J. Sediment. Petrol., 46:280-300.

Hay, W. W., Southam, J. R., 1977. Modulation of marine sedimentation by the continental shelves. In Andersen, N. R., and Malahoff, A. (Eds.), The Fate of Fossil Fuel $\mathrm{CO}_{2}$ in the Oceans: New York (Plenum), pp. 569-603.

Hohberger, K. H., and Einsele, G., 1979. Die Bedeutung des Lösungsabtrags verschiedener Gesteine für die Landschaftsentwicklung in Mitteleuropa. Z. Geomorphol. N.S., 23(4):361-382.

Holeman, J. N., 1968. The sediment yield of major rivers of the world. Water Resourc. Res., 4(no, 4):737-747.

Karig, D. E., and Jensky, W., 1972. The proto-Gulf of California. Earth Planet. Sci. Lett., 17:169-174.

King, P. B., 1969. The Tectonics of North America: A Discussion to Accompany the Tectonic Map of North America, Scale 1: 5,000,000. Geol. Surv. Prof. Pap. (U.S.) 628.

Kinsman, D. J. J., 1975. Rift valley basins and sedimentary history of trailing continental margins. In Fischer, A. G. (Ed.), Petroleum and Global Tectonics: Princeton (Princeton Univ. Press), pp. $82-127$.

Langbein, W. B., and Schumm, S. A., 1958. Yield of sediment in relation to mean annual precipitation. Trans. Am. Geophys. Union., 39:1076-1084.

Larson, R. L., 1972. Bathymetry, magnetic anomalies, and plate tectonic history of the mouth of the Gulf of California. Geol. Soc. Am. Bull., 83:3345-3360.

McCulloh, T. H., 1967. Mass Properties of Sedimentary Rocks and Gravimetric Effects of Petroleum and Natural Gas Reservoirs. Geol. Surv. Prof. Pap. (U.S.) 528-A.

McDowell, F. W., and Keizer, R. P., 1977. Timing of mid-Tertiary volcanism in the Sierra Madre Occidental between Durango City and Mazatlán, Mexico. Geol. Soc. Am. Bull., 88:1479-1487.

Maderey Rascón, L. E., 1977. El agua de escurrimiento en la República Méxicana: Mexico, (U.N.A.M.).
Mathews, W. H., 1975. Cenozoic erosion and erosion surfaces of eastern North America. Am. J. Sci., 275:818-824.

Meade, R. H., 1969. Errors in using modern stream-load data to estimate natural rates of denudation. Geol. Soc. Am. Bull., 80: 1265-1274.

Menard, H. W., Smith, S. M., and Pratt, R. M., 1965. The Rhone Deep-Sea Fan. In Whitard, W. F., and Bradshaw, R. (Eds.), Submarine Geology and Geophysics: London (Butterworth), 271-274.

Metzger, D. G., Loeltz, O. J., and Irelna, B., 1973. Geohydrology of the Parker-Blythe-Cibola Area, Arizona and California. Geol. Surv. Prof. Pap. (U.S.) 486-G.

Minch, J. A., and Gastil, R. G., 1973. Tectonic and stratigraphic evidence for Miocene Gulf of California. Bull. Am. Assoc. Pet. Geol., 57:795.

Moore, D. G., 1969. Reflection Profiling Studies of the California Continental Borderland: Structure and Quaternary Turbidite Basins. Geol. Soc. Am. Spec. Pap. 107.

1973. Plate-edge deformation and crustal growth, Gulf of California structural province. Geol. Soc. Am. Bull., 84: 1883-1906.

Moore, D. G., and Buffington, E. C., 1968. Transform faulting and the growth of the Gulf of California since late Miocene. Science, 161:1238-1241.

Morgan, R. P. C., 1979. Topics in Applied Geography: Soil Erosion: London and New York (Longman).

Morton, P. K., 1977. Geology and Mineral Resources of Imperial County, California. Calif. Div. Mines Geol. Cty. Rep. 7.

Niemitz, J. W., 1977. Tectonics and geochemical exploration for heavy metal deposits in the southern Gulf of California [Ph.D. dissert.]. University of Southern California.

Niemitz, J. W., and Bischoff, J. L., 1981. Tectonic elements of the southern Gulf of California. Geol. Soc. Am. Bull., 92:360-407.

Ortlieb, L., 1978. Marine terraces in northwestern Mexico: A transverse study from the Pacific coast to the Sonora mainland through Baja California peninsula. International Symposium on Coastal Evolution in the Quaternary, São Paulo, Brazil, 1978. (Abstract)

Rabbitt, M. C., McKee, E. D., Hunt, C. B., and Leopold, L. B., 1969. The Colorado River Region and John Wesley Powell. Geol. Surv. Prof. Pap. (U.S.) 669.

Reading, H. G. (Ed.), 1978. Sedimentary Environment and Facies: Oxford (Blackwell).

Rice, R. J., 1980. Rates of erosion in the Little Colorado valley, Arizona. In Cullingford, R. A., Davidson, D. A., and Lewin, J. (Eds.), Timescales in Geomorphology: New York (Wiley Interscience), pp. 317-331.

Rieke, H. H., III, and Chilingarian, G. V., 1974. Compaction of Argillaceous Sediments. Dev. Sedimentol., 16: Amsterdam (Elsevier).

Robinson, P., Lewis, B. T. R., et al., in press. Init. Repts. DSDP, 65: Washington (U.S. Govt. Printing Office).

Roll, A., 1979. Versuch einer Volumenbilanz des Oberrheintalgrabens und seiner Schultern. Geol. Jahrb. A, 52:3-82.

Ross, D. A., Neprochnov, Y. P., et al., 1978. Init. Repts. DSDP, 42, Washington (U.S. Govt. Printing Office).

Ross, D. A., Stoffers, P., and Trimonis, E. S., 1978. Black Sea sedimentary framework. In Ross, D. A., Neprochnov, Y. P., et al., Init. Repts. DSDP, 42, Pt. 2: Washington (U.S. Govt Printing Office), 359-363.

Schlager, W., 1974. Preservation of cephalopod skeletons and carbonate dissolution on ancient Tethyan sea floors. In Hsu, K. J., and Jenkyns, H. C. (Eds.), Pelagic Sediments. Spec. Publ. Int. Assoc. Sedimentol., pp. 11.4.4.-11.4.5.

Selby, M. J., 1974. Rates of denudation. N. Z. J. Geog., 56:1-13.

Sharman, G. F., 1976. The plate tectonic evolution of the Gulf of California [Ph.D. dissert.]. University of California, San Diego.

Shepard, F. P., 1964. Sea-floor valleys of Gulf of California. In van Andel, Tj. H., and Shor, G. G. (Eds.), Marine Geology of the Gulf of California: A Symposium. Am. Assoc. Pet. Geol. Mem. 3: Tulsa (AAPG), 157-192.

Stewart, J. H., 1978. Basin-range structure in western North America: A review. In Smith, R. B., and Eaton, G. P. (Eds.), Cenozoic Tectonics and Regional Geophysics of the Western Cordillera. Geol. Soc. Am. Mem. 152:1-31.

Strahler, A. N., 1969. Physical Geography (3rd ed.): New York (Wiley). 
Thiede, J., 1978. Pelagic sedimentation in immature ocean basins. In Ramberg, I. B., and Neumann, E. R. (Eds.), Tectonics and Geophysics of Continental Rifts. NATO Advanced Study Institutes Series C, 37: Holland (Reidel), 237-248.

1979. History of the North Atlantic Ocean: Evolution of an asymmetric zonal paleo-environment in a latitudinal ocean basin. In Talwani, M., Hay, W., and Ryan, W. B. F. (Eds.), Deep Drilling Results in the Atlantic Ocean: Continental Margins and paleo-Environment. Am. Geophys. Union, Maurice Ewing Ser. 3: 275-296.

Thiede, J., Suess, E., and Müller, P. J., in press. Late Quaternary fluxes of major sediment components to the sea floor at the northwest African continental slope. In von Rad, U. (Ed.), Geology of the Northwest African Continental Margin: Berlin (SpringerVerlag).

van Andel, Tj. H., 1964. Recent marine sediments of Gulf of California. In van Andel, Tj. H., and Shor, G. G. (Eds.), Marine Geology of the Gulf of California: A Symposium. Am. Assoc. Pet. Geol. Mem. 3: Tulsa (AAPG), 216-310. van Andel, Tj. H., and Shor, G. G. (Eds.), 1964. Marine Geology of the Gulf of California: A Symposium. Am. Assoc. Pet. Geol. Mem. 3: Tulsa (AAPG).

van Andel, Tj. H., Thiede, J., Sclater, J. G., and Hay, W., 1977. Depositional history of the South Atlantic Ocean during the last 125 million years. J. Geol, 85:651-698.

von Rad, U., and Einsele, G., 1980. Mesozoic-Cainozoic subsidence history and palaeobathymetry of the northwest African continental margin (Aaiun Basin to DSDP Site 397). Phil. Trans. R. Soc. London Ser. A, 294:37-50.

Watts, A. B., and Ryan, W. B. F., 1976. Flexure of the lithosphere and continental margin basins. Tectonophysics, 36:25-44.

Watts, A. B., and Steckler, M. S., 1979. Subsidence and eustasy at the continental margin of eastern North America. In Talwani, M., Hay, W., Ryan, W. B. F. (Eds.), Deep Drilling Results in the Atlantic Ocean: Continental Margins and Paleoenvironment. Am. Geophys. Union, Maurice Ewing Series 3:218-234.

Wischmeier, W. H., 1977. Soil erodibility by rainfall and runoff. In Toy, T. J. (Ed.), Erosion, Research Techniques, Erodibility and Sediment Delivery: Norwich (Geobooks). 